\title{
An Analysis of Fuel Shares in the Residential Sector: 1960 to 1995
}

J. M. Reilly

S. A. Shankle

J. S. Pomykala

August 1986

Prepared for the U.S. Department of Energy under Contract DE-AC06-76RLO 1830

Pacific Northwest Laboratory Operated for the U.S. Department of Energy Battelle Memorial Institute 


\section{DISCLAIMER}

This report was prepared as an account of work sponsored by an agency of the United States Government. Neither the United States Government nor any agency thereof, nor any of their employees, makes any warranty, express or implied, or assumes any legal liability or responsibility for the accuracy, completeness, or usefulness of any information, apparatus, product, or process disclosed, or represents that its use would not infringe privately owned rights. Reference herein to any specific commercial product, process, or service by trade name, trademark, manufacturer, or otherwise, does not necessarily constitute or imply its endorsement, recommendation, or favoring by the United States Government or any agency thereof. The views and opinions of authors expressed herein do not necessarily state or reflect those of the United States Government or any agency thereof.

\section{PACIFIC NORTHWEST LABORATORY} operated by

BATTELLE

for the

UNITED STATES DEPARTMENT OF ENERGY

under Contract DE-AC06-76RLO 1830

\begin{tabular}{|c|c|}
\hline \multicolumn{2}{|c|}{ Printed in the United States of America } \\
\hline \multirow{2}{*}{\multicolumn{2}{|c|}{$\begin{array}{l}\text { Available from } \\
\text { chnical Information Service }\end{array}$}} \\
\hline & \\
\hline \multicolumn{2}{|c|}{ United States Department of Commerce } \\
\hline \multicolumn{2}{|c|}{5285 Port Royal Road } \\
\hline \multicolumn{2}{|c|}{ Springfield, Virginia 22161} \\
\hline \multicolumn{2}{|c|}{$\begin{array}{l}\text { NTIS Price Codes } \\
\text { Microtiche A01 }\end{array}$} \\
\hline & \\
\hline \multicolumn{2}{|c|}{ Printed Copy } \\
\hline & Price \\
\hline Puges & Codes \\
\hline 001-025 & $\mathrm{A} 02$ \\
\hline $026-050$ & $\mathrm{~A} 03$ \\
\hline $051-075$ & $\mathrm{AO4}$ \\
\hline $076-100$ & A05 \\
\hline $101-125$ & A06 \\
\hline $126-150$ & $\mathrm{~A} 07$ \\
\hline $151-175$ & $A 0 B$ \\
\hline $176-200$ & $\mathrm{~A} 09$ \\
\hline $201-225$ & A010 \\
\hline $226 \cdot 250$ & A011 \\
\hline $251-275$ & A012 \\
\hline $276-300$ & $A 013$ \\
\hline
\end{tabular}


AN ANALYSIS OF FUEL SHARES IN THE

RESIDENTIAL SECTOR: 1960 TO 1995

J. M. Reilly

S. A. Shankle

J. S. Pomykala

August 1986

Prepared for the

U.S. Department of Energy under

Contract DE-AC06-76RLO 1830

Pacific Northwest Laboratory Richland, Washington 99352 


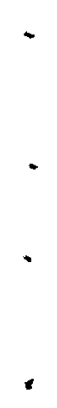




\section{EXECUTIVE SUMMARY}

The purpose of this report is to examine historical and likely future shares of energy use by fuel type in the residential sector of the United States. Of interest is the likely relative demand for fuels as they affect national policy issues such as the potential shortfall of electric generating capacity in the mid to late 1990's and the ability of the residential sector to switch rapidly among fuels in response to fuel shortages, price increases and other factors. The study builds upon previous work conducted by Pacific Northwest Laboratory (PNL) for the U. S. Department of Energy (DOE) in which historical trends in residential energy use were examined and underlying causes of changing aggregate intensity of energy use were identified. (a) The primary focus of the analysis presented here was the factors affecting the share of a fuel used rather than the aggregate level of energy use. However, the share of a fuel used is not independent of the level of energy consumption. In the analysis, the level of consumption of each fuel is computed as an intermediate result and is reported for completeness.

The approach taken in this study was to review historical trends in fuel shares and the literature examining factors affecting fuel use. In doing so, several issues were identified that are likely to affect future fuel shares and the ability of households to easily switch fuels including penetration of technologies, access to the natural gas distribution system, and auxiliary heating capability. Important factors affecting fuel shares were then incorporated in a projection model. This allowed the projection of fuel shares to 1995. The model was based on the DOE 1981 Residential Energy Consumption Survey (RECS) data and used regression analysis to identify the quantify the impact of various factors on fuel use. It has been developed for use on a personal computer. Regional variation was examined by estimating individual equations for each of the four census regions. Variation in fuel use for different housing types was examined by estimating separate equations for each of three housing types, mobile homes, single family homes, and multi-family units. A base case estimate of fuel shares in 1995 was developed. Next, the sensitivity of fuel shares to changes in six underlying factors was examined:

(a) Adams, et. al, 1985. 
- Snow Belt to Sun Belt migration,

o electricity prices,

o $0 i 1$ prices,

- gas prices,

- personal income, and

- technology penetration.

Additional scenario analysis was conducted to examine the impact of temporary and prolonged oil price shocks, the combined impact of all high and all low energy prices, and the impact of high electricity prices combined with low oil and gas prices.

Figure E.1 illustrates the historical (1960-1984) and projected changes in fuel shares for 1984 to 1995 . The general result is that electricity use grows as a share of total fuel use. Most of this growth in the share of electricity is at the expense of $0 i 1$, however, the gas share declines slightly from 1986 through 1995. This trend reflects the continued phasing out of oil

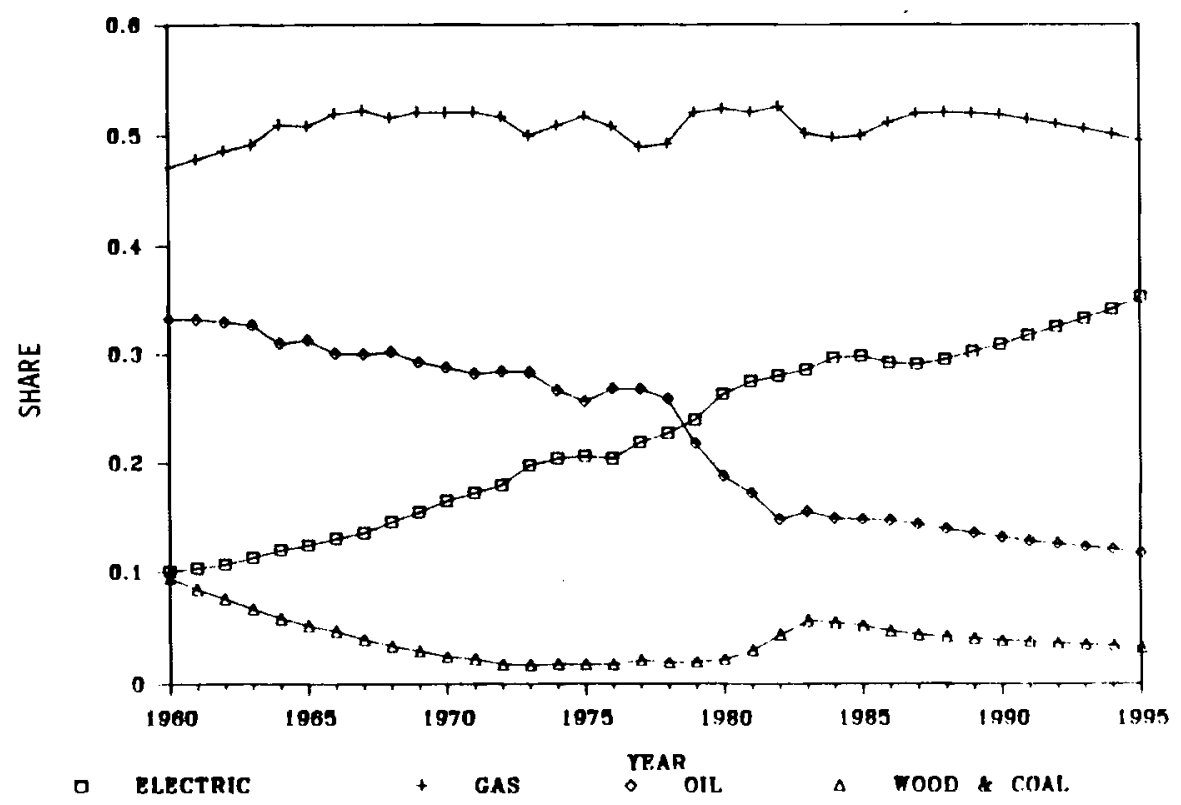

Figure E.1. Historical and Projected Fuel Shares 
as a heating fuel due to price and non-price considerations (it is relatively dirty and inconvenient). The gains for electricity are primarily due to relative price changes favoring electricity over gas and, more importantly, to significant penetration of electric heat pumps. Part of this penetration will be spurred by relative fuel price considerations but much is due to maturation of and public acceptance of the technology. The projected trends tend to reflect the same general pattern as that exhibited during the historical period. The oil share declines at a much more moderate rate than during the 1970's; the decline is more like that exhibited during the 1960 's.

There are, however, a considerable number of factors that could significantly alter the picture from that described above as indicated by the scenario analyses. For example, rising electricity prices combined with falling gas and oil prices could lead to no further penetration of electricity. Rapid penetration of the electric heat pump could, on the other hand, lead to electricity penetration to 38.5 percent of fuel use in 1995, up from 29.9 percent in 1985. Such uncertainties could have significant impacts one way or the other on the likelihood of electricity supply shortfalls in the 1990's.

Overall, the forecasts of aggregate fuel use are higher than have been projected by such forecasters as the Energy Information Administration (EIA). (a) The EIA base case forecasts 10.03 quads of residential energy use in 1995 compared to our 11.88 quads. This difference is largely due to energy prices; our all high price case is approximately the same as the EIA base case and total energy use in our all high price case is 10.66 quads.

Among the factors likely to have an impact on future fuel shares, gas prices are likely to be most important followed by electricity prices, trend penetration of heat pumps, oil prices, and population shift to the South and West. Income was found to have little effect on fuel shares.

A significant finding was the prevalence of auxiliary and multi-fuel heating capability in the residential sector; 20 to 35 percent, depending on primary heating fuel, of single family homes have dual fuel capability. In particular, 35 percent of homes heated primarily with oil have multi-fuel capability and used this capability to provide a substantial proportion of
(a) See EIA, 1986, p.48. 
their heating requirements in 1981. The prevalence of dual-fuel heating capability is an apparent response to the volatility and uncertainty in oil prices. Because significant dual-fuel capability exists, many households are well situated to respond easily and quickly to oil price shocks and oil shortages. 
TABLE OF CONTENTS

EXECUTIVE SUMMARY ................ i i ...

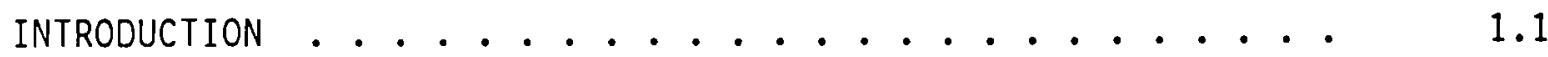

HISTORICAL FUEL SHARES AND OUTSTANDING ISSUES . . . . . . 2.1

HISTORICAL FUEL SHARES ............... 2.1

ISSUES ........................... 2.3

DUAL FUEL AND AUXILIARY HEATING

CAPABILITY IN THE RESIDENTIAL SECTOR ......... 2.7

PROJECTION METHODOLOGY . . . . . . . . . . . . . 3.1

PROJECTED FUEL SHARES AND SENSITIVITY ANALYSIS . . . . . . 4.1

bASE CASE ASSUMPTIONS . . . . . . . . . . . 4.1

BASE CASE RESULTS .................... 4.2

SENSITIVITY OF RESULTS TO CHANGE

IN ASSUMPTIONS .......................... 4.4

THE OUTLOOK FOR FACTORS AFFECTING FUEL SHARES. . . . . . 4.6

SENSITIVITY RESULTS . . . . . . . . . . . . 4.7

SCENARIO ANALYSIS OF FUEL PRICES . . . . . . . . 4.20

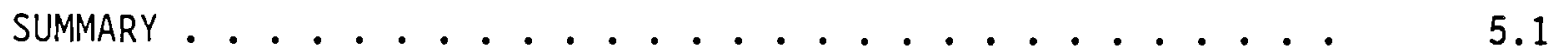

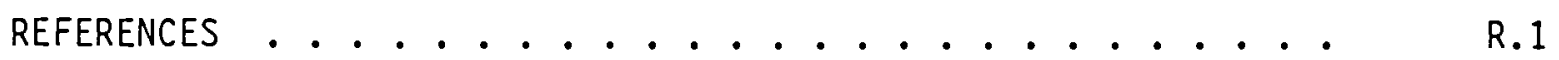




\section{FIGURES}

E.1 Historical and Projected Fuel Shares .......... . iv

2.1 Historical Fuel Shares............... . 2.2

3.1 Components of Fuel Shares Projection Methodology . . . . . 3.2

3.2 Census Regions . . . . . . . . . . . . . 3.3

4.1 Base Case Fuel Price Assumptions . . . . . . . . . 4.3

4.2 Historical and Projected Fuel Shares . . . . . . . . 4.4

4.3 $0 i 1$ Price Shocks . . . . . . . . . . . . . . 4.21 


\section{$\underline{\text { TABLES }}$}

2.1 Historical Fuel Use . . . . . . . . . . . . . 2.2

2.2 Prevalence of Multi-Fuel Capability . . . . . . . 2.10

2.3 Contribution of Auxiliary

Equipment to Space Heating Requirements . . . . . . . 2.12

3.1 Electricity Variables . . . . . . . . . . . . 3.11

3.2 Natural Gas Variables... . . . . . . . . . 3.12

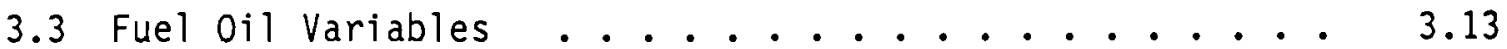

4.1 Future Values of Exogenous Assumptions . . . . . . . . 4.1

4.2 Energy use In the Residential Sector by Fuel . . . . . 4.5

4.3 Summary of Sensitivity Results . . . . . . . . . 4.3

4.4 High Gas Prices . . . . . . . . . . . . . . 4.9

4.5 Low Gas Prices ................... . 4.10

4.6 High Electric Prices ................ 4.11

4.7 Low Electric Prices . . . . . . . . . . . 4.12

4.8 Heat Pump Penetration. . . . . . . . . . . . 4.13

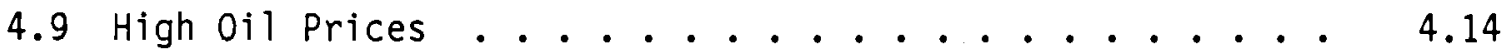

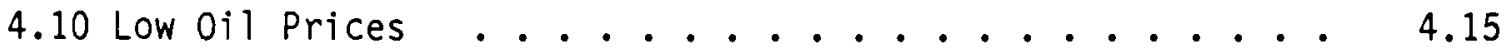

4.11 High Migration to the South and West . . . . . . . . 4.16

4.12 Slow Migration to the South and West . . . . . . . 4.17

4.13 High Income . . . . . . . . . . . . . . 4.18

4.14 Low Income . . . . . . . . . . . . . . . 4.19

4.15 Temporary 0il Price Shock . . . . . . . . . . 4.22

4.16 Permanent $0 i l$ Price Shock . . . . . . . . . . 4.23

4.17 High Fuel Prices . . . . . . . . . . . . . . . 4.24

4.18 Low fuel Prices . . . . . . . . . . . . . . 4 4.25

4.19 High Electric Prices, Low Gas and 0il Prices . . . . . 4.26 
.
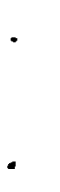


\subsection{INTRODUCTION}

The purpose of this report is to examine historical and likely future shares of energy use by fuel type in the residential sector of the United States. Of interest is the likely relative demand for fuels as they affect national policy issues such as the potential shortfall of electric generating capacity in the mid to late 1990's and the abllity of the residential sector to switch rapidly among fuels in response to fuel shortages, price increases and other factors. The study builds upon previous work conducted by Pacific Northwest Laboratory (PNL) for the U.S. Department of Energy (DOE) in which historical trends in residential energy use were examined and underlying causes of changing aggregate intensity of energy use were identified. (a) The primary focus of the analysis presented here was the factors affecting the share of a fuel used rather than the aggregate level of energy use. However, the share of a fuel used is not independent of the level of energy consumption. For example, improved efficiency of gas furnaces will reduce energy use per household for those households employing the new furnace and may also encourage further penetration of gas furnaces by reducing the effective fuel cost of heating with gas; aggregate fuel use is reduced while the impact on the share of gas is uncertain. Similarly, an increase in the price of a fuel will result in both conservation actions that reduce use of the fuel (and therefore aggregate energy use) and fuel-switching away from the fuel. These two examples illustrate the inseparability of the fuel share and aggregate level of fuel use.

The approach taken in this study was to review historical trends in fuel shares and the literature examining factors affecting fuel use. In doing so, several issues were identified that are likely to affect future fuel shares and the ability of households to switch easily fuels including penetration of technologies, access to the natural gas distribution system, and auxiliary heating capability. The review of historical trends and analysis of issues affecting fuel shares is reported in Section 2.0. Important factors affecting fuel shares were then incorporated in a projection model. This allowed the projection of fuel shares to 1995 . Scenario analysis was conducted to address

(a) Adams, et. al, 1985. 
the issue of how the projected shares vary with variation in fuel prices, income, household size, technology penetration, and regional population shifts. Methodological issues associated with development of the forecast model are discussed in Section 3.0. Section 4.0 presents a base case for residential fuel shares and reports the results of scenario analysis. Section 5.0 offers a summary of results. 


\subsection{HISTORICAL FUEL SHARES AND OUTSTANDING ISSUES}

Factors affecting fuel use, and therefore affecting fuel shares, have been analyzed extensively. This chapter examines the historical trend in fuel shares from 1960 to 1984 and briefly discusses factors generally agreed on as important determinants of fuel use. In addition, the existence of dualfuel and auxiliary heating equipment is identified as a previously unresearched topic. This chapter provides a detailed analysis of dual-fuel heating capability in the residential sector and its contribution to meeting heating requirements.

\subsection{HISTORICAL FUEL SHARES}

The historical record for the residential sector from 1960 to the present shows several clear trends in the percentage of energy accounted for by individual fuels (Figure 2.1 and Table 2.1). Coal has nearly been eliminated as a residential fuel; while coal accounted for 6 percent of total fuel use in 1960 its share gradually declined so that by 1984 it accounted for less than 1 percent of fuel use. While estimates of the energy value of wood use for homes heated primarily with wood are not as reliable as estimates of the consumption of other fuels, estimated wood use paralleled the pattern of coal from 1960 through most of the 1970's. (a) Beginning in 1979, however, wood use has increased rapidly. The other apparent trend is the continued increase in electricity use and decline in the share of oil use. Electricity use increased from 10 percent to nearly 30 percent of total residential energy use over the period while oil use declined from 33 percent to 15 percent. Penetration of electricity has, if anything, been accelerating gradually over

(a) The energy value of wood use was estimated as the amount of natural gas that would have been used if heating services had been provided by a gas furnace.Natural gas use was estimated to equal the average 1981 rate for the housing type/region at average income/climate/price/etc. levels. Natural gas was chosen as the fuel substitute because it is the dominant fuel, particularly in the regions with large numbers of wood stoves. Estimates of number of primary wood heating units are from the Census Bureau as reported in EIA (1985), p. 53. Census Bureau estimates were available for 1960, 1970, 1973-1981, 1983. Values for missing years were linearly interpolated. The resultant estimates of the contribution of wood to residential energy demand are not estimates of the energy content of the wood used but estimates of the offset to commercial fuels. 


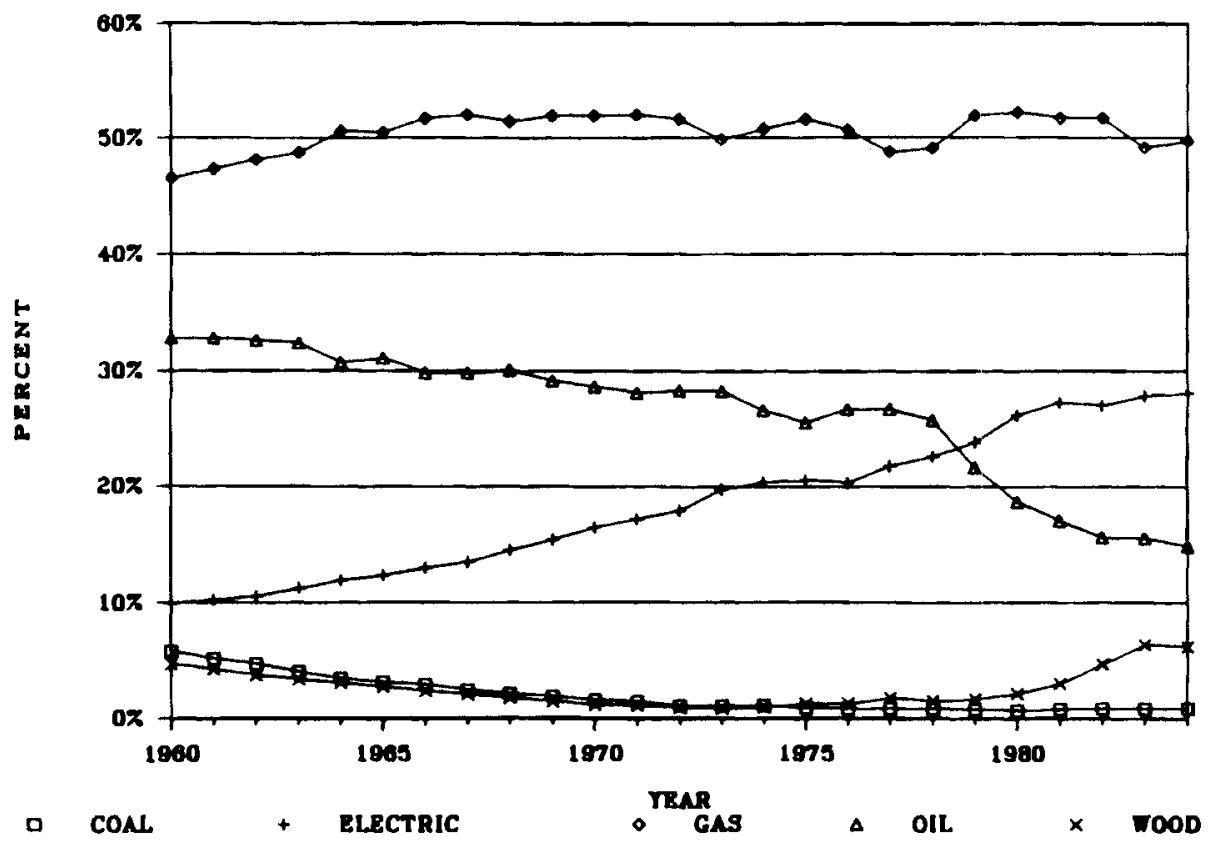

EIGURE 2.1. Historical Fuel Shares

IABLE 2.1. Historical Fuel Use

(QUADS)

\begin{tabular}{rrrrrrr} 
YEAR & ELECTRICITY & GAS & OIL & \multicolumn{1}{l}{ COAL } & WOOD & TOTAL \\
\hline 1960 & 0.6874 & 3.2118 & 2.2653 & 0.4050 & 0.2382 & 6.8077 \\
1961 & 0.7317 & 3.3623 & 2.3319 & 0.3689 & 0.2228 & 7.0176 \\
1962 & 0.7943 & 3.6003 & 2.4409 & 0.3543 & 0.2074 & 7.3972 \\
1963 & 0.8556 & 3.7003 & 2.4594 & 0.3084 & 0.1920 & 7.5157 \\
1964 & 0.9275 & 3.9085 & 2.375 & 0.2708 & 0.1765 & 7.6583 \\
1965 & 0.9929 & 4.0277 & 2.4806 & 0.2525 & 0.1611 & 7.9148 \\
1966 & 1.0812 & 4.2748 & 2.4707 & 0.2443 & 0.1457 & 8.2167 \\
1967 & 1.1605 & 4.4513 & 2.5568 & 0.2104 & 0.1303 & 8.5093 \\
1968 & 1.3019 & 4.5883 & 2.6852 & 0.1905 & 0.1149 & 8.8808 \\
1969 & 1.456 & 4.8749 & 2.7387 & 0.1773 & 0.0994 & 9.3463 \\
1970 & 1.591 & 4.9874 & 2.7552 & 0.1523 & 0.0840 & 9.5699 \\
1971 & 1.7044 & 5.1258 & 2.7771 & 0.1436 & 0.0773 & 9.8282 \\
1972 & 1.8377 & 5.2644 & 2.8954 & 0.1103 & 0.0705 & 10.1783 \\
1973 & 1.9763 & 4.977 & 2.8252 & 0.1081 & 0.0638 & 9.9504 \\
1974 & 1.9728 & 4.901 & 2.5735 & 0.1060 & 0.0702 & 9.6235 \\
1975 & 2.0067 & 5.0226 & 2.4949 & 0.0865 & 0.0904 & 9.7011 \\
1976 & 2.0692 & 5.1473 & 2.7204 & 0.0839 & 0.0968 & 10.1176 \\
1977 & 2.2016 & 4.9131 & 2.695 & 0.0845 & 0.1319 & 10.0261 \\
1978 & 2.3013 & 4.9815 & 2.6199 & 0.0853 & 0.1138 & 10.1018 \\
1979 & 2.3298 & 5.0547 & 2.1137 & 0.0743 & 0.1212 & 9.6937 \\
1980 & 2.4481 & 4.8661 & 1.7479 & 0.0613 & 0.1468 & 9.2702 \\
1981 & 2.4644 & 4.6647 & 1.5434 & 0.0729 & 0.2010 & 8.9464 \\
1982 & 2.4898 & 4.6746 & 1.3176 & 0.0776 & 0.3180 & 8.8776 \\
1983 & 2.5955 & 4.5586 & 1.4125 & 0.0777 & 0.4350 & 9.0793 \\
1984 & 2.8050 & 4.7091 & 1.4104 & 0.0835 & 0.4350 & 9.4431
\end{tabular}


the period. The share of oil use had shown a fairly constant declining trend (with some variability around the trend) through 1978. After 1978 this trend was significantly accelerated. The gas share has been most erratic. Comparing the 1980 gas percentage to the 1960 percentage shows an increase of over 5 percentage points. However as recently as 1977 , the gas share was within a percentage point of the 1960 level and in 1984 it was 3 percentage points over the 1960 level.

\subsection{ISSUES}

Residential energy demand has been analyzed extensively. (a) Among the factors affecting fuel shares, relative fuel prices are most frequently identified and analyzed in the literature. ${ }^{(b)}$ The coincidence of the drop in the share of oil, starting in 1979, and rapid increase in the price of oil gives support for this view. However, prices alone fail to explain the consistent trends in oil, coal, and electricity because there was little trend in prices prior to 1972 but significant trends in fuel shares. Moreover, the price response to the quadrupling of world oil prices between 1972 and 1974 was much weaker than the response to the doubling of ofl prices in 1979-1980. (c)

Cursory knowledge of energy use in the residential sector suggests that, for practical purposes, fuel switching is limited by the household energy-using capital in-place and generally available technology; e.g. the existence of an oil furnace limits heating energy demand to oil while the existence of a gas furnace limits heating energy demand to gas. The implication is that the short run variability in fuel shares is limited to variability in the intensity with which appliances, space heating and cooling equipment, and water heating equipment are used. In the longer run, the household can replace equipment (switch fuels) and weatherproof the house to further alter fuel use. The

(a) MCDougall, et al. 1981 provides a useful review of studies.

(b) Estimation of the impact of fuel prices on own and competing fuel use is usually reduced to estimates of own- and cross-price elasticity responses. There are several comprehensive reviews of this literature, including Taylor (1977), Edmonds (1978), and Bohi (1981).

(c) Scheer, et.al. (1985) examine the impacts of price shocks on the efficiency of aggregate energy use, exploring several hypothesis that may explain differential response to past price shocks. 
explicit recognition of energy use conditioned on the equipment stock provides a fairly obvious and direct explanation for changing trends (over the long term) in fuel shares, i.e. changing stocks of household energy-using equipment. (a) Fuel prices play a role in equipment and appliance choice and decisions on insulation and weatherproofing but other factors are important as well. In particular, improvements in technology and the introduction and penetration of new technologies can have a significant impact. (b)

The most direct example of this in the residential sector is the introduction and penetration of electric heat pumps. The concept of the heat pump existed for years until the rapid escalation of $0 i 1$ and gas prices encouraged the commercial development of heat pumps designed for the residential housing market. Heat pumps have gained a significant share of new sales of heating equipment (16 percent in 1980). They represent only 1 to 2 percent of the existing stock of heating equipment, however, because the stock only adjusts gradually as existing equipment is replaced. Thus, even if the market share for heat pumps is unchanged one can expect continued increases in the share of heat pumps in the stock of equipment in-place and, therefore, increases in the share of electricity use.

Other "new" technologies such as air conditioning have continued to penetrate and have not yet fully saturated the market. Recognition of the potential importance of such trends is only limitedly useful in the examination of historical trends in fuel shares because limited data exist on stocks of heating and cooling equipment and no data exist for major appliance stocks in households for years prior to 1978. (c) Penetration of new technologies,

(a) The explicit recognition of technology/appliance choice is the basis for many recent residential energy models. See, for example, Arthur D. Little, Inc., 1981; Cambridge Systematics, Inc., 1981; Charles River Associates, Inc., 1980; Hartman, 1979, 1982a, b, 1984; Hartman and Wallace, 1982; Hausman, 1979; Hirst and Carney, 1978.

(b) Factors driving technology penetration have been analyzed by Griliches (1957), Mansfield (1961), Paterka (1977), and, with specific reference to energy systems, Marchetti and Nakicenovic (1979).

(c) The Residential Energy Consumption Survey (RECS) of the Energy Information Administration collected such information on a national basis for the first time in 1978. Summary data are published in EIA, 1985 p. 55. 
improvements in efficiency of technologies, and factors such as income, household size, housing type, and geographic location affect aggregate energy use in the residential sector and may affect fuel shares as well if the factor has a differential effect on one fuel over another.

For example, homes in the North East are more likely to use oil heat and face higher heating requirements and lower cooling requirements than homes in the South. Thus, a regional population shift from the North East to the South is likely to lead to a reduction in the oil share and an increase in the electricity share and reduced overall energy use. Homes in the North Central region are more likely to be heated with gas and as a result a population shift from the North Central leads to a fall in the gas share. The introduction of numerous small electric appliances (without a comparable increase in gas or oil appliances) increases the electricity share. Higher income may favor electric heat (for its cleanliness and convenience) over oil or gas. These factors are further identified in Section 3.0.

\subsubsection{Access to Natural Gas}

An additional factor explaining fuel shares and limiting the capability of households to switch among fuels is access to fuels. This issue is most critical in the case of natural gas where the lack of a pipeline distribution system in an area prohibits residents from using natural gas. An estimated 80 percent of households have access to natural gas. (a) Natural gas access is particularly limited in the Northeast and Pacific Northwest. Households without access to a natural gas distribution system have a near-substitute in liquified petroleum gas (LPG). LPG has the same clean-burning properties and can be used with gas appliances to provide energy services.

\subsubsection{Average versus Marginal Prices of Fuels}

Another issue discussed in the literature is the marginal versus average price of fuels. The block rate structure of electricity prices creates a situation where marginal prices are not equal to average prices. Changes in connection charges and charges for the first blocks of electricity use may leave the price (at the margin) that the consumer faces unchanged but will

(a) The American Gas Association has estimated the share of households with access to gas. The issue is further examined in U.S. DOE, Increasing Competition in the Natural Gas Market. 
change the average price (the total bill divided by kwh's of use). It is expected that price structure changes that do not affect the marginal price will act like an income effect; increases will reduce available income and therefore reduce consumption of all goods including electricity. The impact of changing marginal prices is akin to the normal price changes of other goods; that is, they have a combined income and substitution effect. For this reason, it is usually argued that price responses should be estimated on the basis of marginal prices.

The RECS data includes information on the block structure of electricity prices but there are two major problems with the data. First, to preserve confidentiality of the respondents, three standard blocks are reported rather than the actual individual block structures which vary considerably across utilities. Second the block structure is missing for over half the sample. To overcome the second problem, average marginal prices for each block were estimated for each of the nine census divisions and these regional averages were assigned to observations with missing data based on the electricity block within which an individual fell.

Equations with the marginal price, the average price, and with both prices were estimated. The marginal price variable was routinely insignificant or of the wrong sign. This result suggests that consumers may react to average price rather than marginal price; $i . e$. the consumer reacts to the size of the bill, possibly using a rule of thumb and controlling for climate by looking at year to year monthly changes. However, it is at least as likely that the marginal price results reflect the poor quality of the data.

\subsubsection{Floorspace}

One would generally expect a positive relationship between the amount of space to be heated and fuel use, all else equal. Estimation of the impact of floorspace heated on heating demand was examined using regression analysis of the RECS data set. Inclusion of a floorspace variable in regression equations failed to show significant results of the expected sign. Several possible explanations exist. First, floorspace does not capture the effect of a room's height which may be a more important determinant of fuel use. Second, subsetting of the data set by housing type, particularly between single family and multi-family, may capture a significant portion of the total sample 
floorspace variability. Thus, variability in floorspace within the subsample may be relatively small. Third, floorspace may be correlated with omitted variables leading to bias in the estimated parameter. In particular, floorspace may be greater for multi-story homes and, due to less roof area, ceiling heat loss in multi-story homes is typically less than in single story homes. Given such a relationship, omission of a variable controlling for number of stories would bias the floorspace variable to zero.

\subsubsection{Housing Vintage}

Technological change in regression analysis is often treated as a constant time trend factor. RECS contains cross section data but includes a variable for housing vintage. One might hypothesize that insulation and other energy-saving techniques have improved over time. Therefore one would expect newer houses to use less energy. However, several confounding factors exist. First, energy-using characteristics of residences of different vintages change due to changing relative prices of construction factors (1abor, building materials, etc.) These historical prices are not contained in the RECS data. observed changes include a period when energy prices were falling relative to other prices (pre-1973), and a period when energy prices rose rapidiy (post-1973). During the pre-1973 period energy efficiency was likely to have been substituted for other inputs. Second, technological change is at least partially induced by relative price changes and is unlikely to be constant across factors. Third, taste changes in housing characteristics (ranch style and split levels versus multi-stories, window types, and amount of glass area) could contribute to a decreasing or increasing energy use trend.

Given the possible problems discussed above, it is not surprising that attempts to include housing vintage showed mixed and insignificant results. Some additional resolution might be gained by adding a pre-and post-1973 dummy variable. It was not possible to examine this issue in greater detail. Given the problems with the variable in its simple form, it was dropped from consideration in the basic regression equations.

\subsection{DUAL FUEL AND AUXILIARY HEATING CAPABILITY IN THE RESIDENTIAL SECTOR}

The rapid increases in the price of oil that occurred during the 1970's and the recent drops in the price have resulted in significant swings in the relative prices of fuels. Capital equipment investment decisions regarding 
energy-using equipment made on the basis of one fuel price regime become "bad" decisions in hindsight when the decisions are based on fuel price expectations that are not realized. The potential cost savings from being able to switch to oil, gas, or coal as the fuel prices change has provided a strong incentive for large industrial fuel users to invest in fuel-using equipment that has dual- or multi-fuel capability.

Multi-fuel capability equipment is one important response of private agents to varying and uncertain fuel prices. Such capabilities have significant implications for public policy. Those fuel users who are able to switch easily incur far lower economic and welfare losses in a shortage situation. As a result, economy-wide losses are lower in a fuel shortage situation and the economy is better able to take advantage of short-term drops in fuel prices. In addition, the ability to rapidly fuel switch greatly increases the demand elasticity for a fuel. By doing so, it makes it much more difficult for fuel suppliers to create a sustained increase in the price of the fuel. Lower prices benefit all consumers whether or not they have dual-fuel capability. This private sector response can greatly reduce the need for government action to allocate fuels or control price increases and is equivalent to a fuel stockpile available in a shortage situation. These benefits are not costless, however, because dual-fuel capability requires additional capital expenditures.

Multi-fuel capability in the residential sector has not been examined in the past, largely on the assumption that it would rarely be economic for a household to purchase redundant equipment to allow rapid fuel switching. In fact, low capital cost auxiliary heating equipment does exist and several innovative technological responses have occurred that allow residences to have multi-fuel capability in space heating at a relatively low cost. Portable electric, LPG, and kerosene heaters are among the low cost auxiliary technologies that can provide the ability to fuel-switch and may further increase energy savings by allowing zonal heating. Fireplace inserts allow households the abllity to turn fireplaces into a contributor to heating requirements. (a)

(a) Conventional fireplaces increase energy use because the draft created in the chimney draws warm air from the house, increasing the heating load on the central furnace. 
Wood-burning furnace add-ons allow the household to heat the house through the existing central furnace duct-work with firewood, off-setting gas or oil use. Such multi-fuel capability has been built into some new furnaces allowing wood/coal/oil, wood/coal/gas, and other combinations. Such devices allow the household to alter fuel use as convenience, fuel availability, and fuel price dictate. Electric heat pump/gas furnace combinations, while a dual fuel capability, do not allow the resident to easily alter the mix of fuels; while such combinations have implications for the future share of fuel use they do not necessarily increase the ability of the household to respond to changing relative prices.

Table 2.2 gives estimates of the proportion of all homes and single family households with different auxiliary heating capability by primary heating fuel in the U.S. for the sample households in the Residential Energy Consumption Survey. (a) The estimated percentages are weighted to provide unbiased estimates for the population. For all households, 37.8 percent have auxiliary heating. Depending on the primary heating fuel, between 45 and 58 percent of single family homes have some type of auxiliary heating capability including fireplaces. Those with oil heat as the primary heat source show the highest proportion of homes with auxiliary heating capability, possibly reflecting the fact that oil prices have been most volatile thereby providing the most economic incentive for dual-heating capability.

The total auxiliary heating figure includes homes with fireplaces. Because fireplaces may actually increase use of the primary heating fuel, they are more appropriately categorized as having aesthetic value rather than value as auxiliary heating equipment. Subtracting fireplaces from the total leaves between 21.7 and 39.5 percent of homes with auxiliary heating. In all homes, the comparable percentage is 24 . Notably, this calculation increases the difference between households with oil as the primary heating source and other households. It also eliminates the difference between all homes and single family homes.

\section{9}

(a) Complete documentation of the methodology used to estimate the contribution of auxiliary heating equipment to meeting space heating requirements in the residential sector is given in Reilly and Shankle (1986). 
IABLE 2.2 Prevalence of Multi-Fuel Capability

(percent of households within category)

\begin{tabular}{|c|c|c|c|c|}
\hline $\begin{array}{l}\text { Auxiliary } \\
\text { Technology }\end{array}$ & $\begin{array}{l}\text { All Homes, } \\
\text { All Fuels }\end{array}$ & $\begin{array}{l}\text { Single Family, } \\
\text { Electricity(a) }\end{array}$ & $\begin{array}{l}\text { Single Family, } \\
\text { Gas(a) }\end{array}$ & $\begin{array}{c}\text { Single Family, } \\
\text { Oil (a) }\end{array}$ \\
\hline $\begin{array}{l}\text { Wood or } \\
\text { Wood/coal } \\
\text { Fireplace }\end{array}$ & 13.8 & 28.9 & 24.1 & 18.7 \\
\hline $\begin{array}{l}\text { Wood or } \\
\text { Coal Stove }\end{array}$ & 4.9 & 12.1 & 4.5 & 17.8 \\
\hline $\begin{array}{l}\text { Portable } \\
\text { Electric } \\
\text { Heaters }\end{array}$ & 7.3 & 4.0 & 6.9 & 11.6 \\
\hline Gas Heater & 2.5 & 1.5 & 3.4 & 1.0 \\
\hline $\begin{array}{l}\text { Electric } \\
\text { Wall Units }\end{array}$ & 3.1 & 1.2 & 3.2 & 4.1 \\
\hline $\begin{array}{l}\text { Portable } 0 \text { ill } \\
\text { Kerosene } \\
\text { Heater }\end{array}$ & 0.6 & 0.6 & 0.8 & 2.1 \\
\hline $\begin{array}{l}\text { Central Gas } \\
\text { Furnace }\end{array}$ & 1.6 & 0.4 & 1.0 & 0.0 \\
\hline Gas Fireplace & 0.7 & 0.4 & 1.3 & 0.0 \\
\hline 0il Heater & 0.7 & 1.0 & 0.3 & 1.9 \\
\hline $\begin{array}{l}\text { Electric } \\
\text { Heat Pump }\end{array}$ & 0.4 & 1.2 & 0.2 & 0.3 \\
\hline $\begin{array}{l}\text { Central } 0 \mathrm{il} \\
\text { Furnace }\end{array}$ & 1.6 & 0.2 & $<.1$ & 0.0 \\
\hline $\begin{array}{l}\text { Central Elec. } \\
\text { Furnace }\end{array}$ & 0.5 & 0.4 & $<.1$ & 0.2 \\
\hline $\begin{array}{l}\text { Central Wood/ } \\
\text { Coal Furnace }\end{array}$ & $<.1$ & 0.0 & $<.1$ & 0.2 \\
\hline Other & 0.1 & 0.0 & $<.1$ & 0.3 \\
\hline Total & 37.8 & 51.9 & 45.8 & 58.2 \\
\hline
\end{tabular}

(a) Fuel used for primary space heating requirements. 
Apart from fireplaces, the most prevalent auxiliary heating equipment types in single family homes are wood stoves, present in 8.1 percent of homes nationwide, and portable electric heaters, present in 7.3 percent of homes. For all homes, electric portable heaters are the most prevalent. Households heated primarily with gas furnaces favor portable electric heaters for auxiliary equipment whereas households heated primarily with electricity and oil favor wood stoves. Electric wall units and gas heaters (3.1 percent and 2.7 percent respectively, in all single family homes) are the next most popular auxiliary heating devices. Interestingly, 1 percent of single family homes with central gas furnaces view these furnaces as auxiliary equipment and report gas heaters as the primary heating device in the home.

Table 2.3 provides estimates of the contribution of the more prevalent auxiliary heating equipment types to meeting space heating requirements in the residential sector. Small sample size made it impossible to estimate reliably the contribution for multi-family and mobile homes and for many of the less prevalent equipment types. The contribution is measured as the offset to fuel used by the primary heating equipment. Table 2.3 reports the contribution as a percentage of the estimated use of the primary heating equipment. A negative entry indicates that for the average household owning the auxiliary equipment their fuel use (in BTU's) was reduced by the reported percentage. Positive entries (in the case of fireplaces) reflect the fact that fireplaces create a draft, drawing warm air from the house and thereby increasing fuel use. Existence of a fireplace showed a consistent increase in fuel use of about 15 percent across fuels. Wood/coal stoves provide the largest offset to primary heating requirements across all fuels. The estimates indicate that wood stoves, when present, are used most intensively in homes heated primarily with oil. 
TABLE 2.3 Contribution of Auxiliary Equipment to Space Heating Requirements (as a percent of primary heating fuel use)

\begin{tabular}{|c|c|c|c|}
\hline $\begin{array}{l}\text { Auxiliary } \\
\text { Technology }\end{array}$ & $\begin{array}{l}\text { Single Family, } \\
\text { Electricity } \\
\end{array}$ & $\begin{array}{c}\text { Single Family, } \\
\text { Gas }\end{array}$ & $\begin{array}{c}\text { Single Family, } \\
0 \mathrm{i} 1\end{array}$ \\
\hline $\begin{array}{l}\text { Wood or } \\
\text { Wood/coal } \\
\text { Fireplace }\end{array}$ & +15.5 & +14.1 & +16.6 \\
\hline $\begin{array}{l}\text { Wood or } \\
\text { Coal Stove }\end{array}$ & -13.9 & -18.5 & -46.5 \\
\hline $\begin{array}{l}\text { Portable } \\
\text { Electric } \\
\text { Heaters }\end{array}$ & -7.4 & 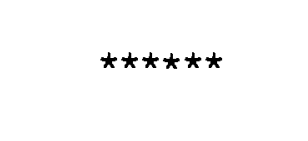 & -1.4 \\
\hline Gas Heater & N.E. & -18.8 & N.E. \\
\hline $\begin{array}{l}\text { Electric } \\
\text { Wall Units }\end{array}$ & N.E. & -0.9 & 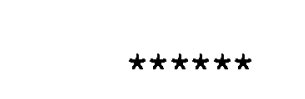 \\
\hline $\begin{array}{l}\text { Central Gas } \\
\text { Furnace }\end{array}$ & N.E. & -65.9 & N.E. \\
\hline
\end{tabular}

See Reilly and Shankle (1986) for documentation of the estimation methodology. 


\subsection{PROJECTION METHODOLOGY}

Figure 3.1 describes the elements involved in projecting fuel shares in the residential sector. (a) First, it is necessary to develop estimates of the housing stock to 1995. Initial conditions in the base year describing the existing housing stock and energy-using appliance stock are given. Changes in the housing stock occur through a combination of new construction and abandonment of existing stock. Decisions regarding heating, air conditioning, water heating technology and other appliances are made when new homes are constructed or when a decision to retrofit or replace the existing stock of equipment is made.

The technology choice decision is based on equipment prices, fuel prices, and other factors and can be separately described for space heating, space cooling, water heating and appliances. It can also be separated for new homes and retrofit/replacement since the relevant factors may vary. For example, electric heat tends to be a more likely choice in new construction because, to make it economic, the housing shell typically must have better insulating characteristics than for other fuels because of the higher fuel cost of electricity. It has also been argued that commercial builders, who typically make decisions about newly constructed homes, may arrive at different decisions than the home owner would if he were building the home. One reason for such differences may be that the housing market does not efficiently capitalize energy fuel savings. (b)

By combining the housing stock estimate and appliance choice estimates, one arrives at estimates of the housing stock and the corresponding stock of energy-using equipment. These estimates, when combined with the appropriate exogenous variables, provide estimates of fuel use and fuel shares for 1995.

The general methodology used was to analyze the DOE 1981 Residential Energy Consumption Survey (RECS) data using regression analysis to identify

(a) The methodology used to project fuel shares is further documented in Reilly (1986).

(b) Johnson and Kaserman, 1983, examine aspects of energy efficiency capitalization in housing market resales. 
Eigure 3.1. Components of Fuel Shares Projection Methodology

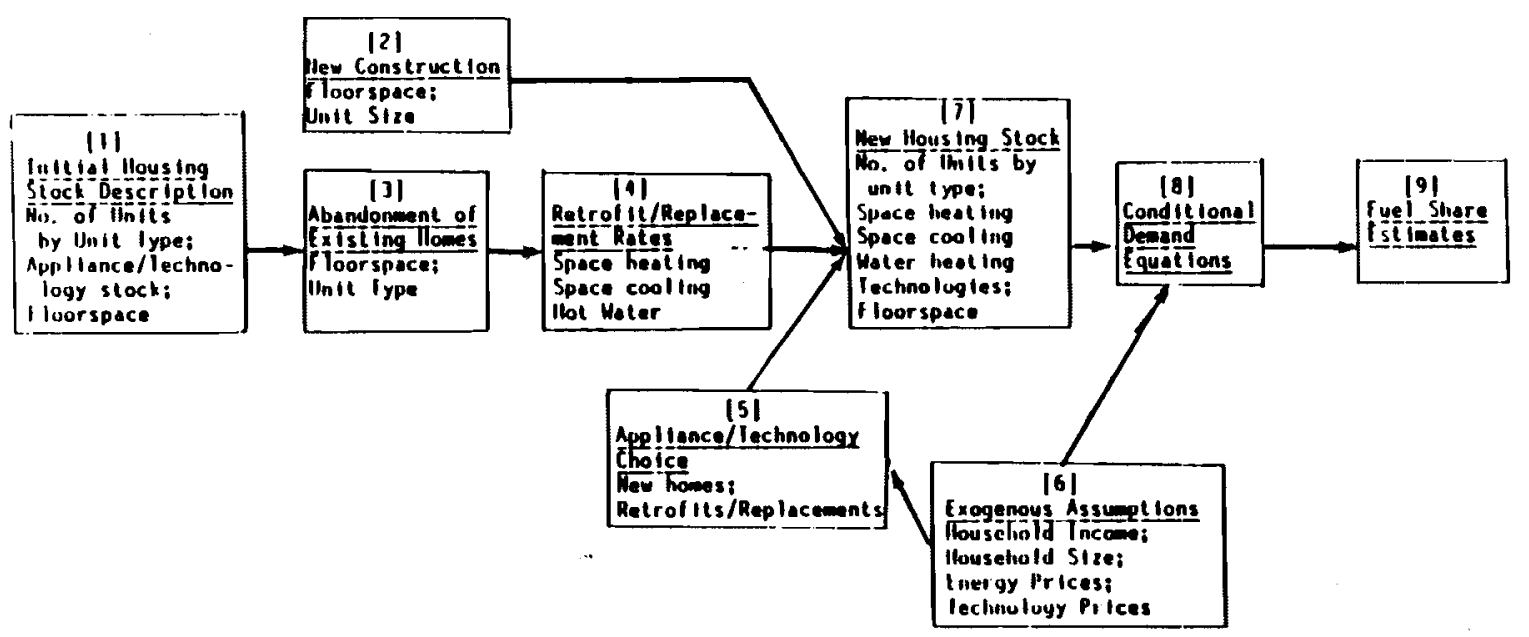

and quantify the impact of various factors on fuel use. Regional variation in fuel use was examined by estimating individual equations for each of the four census regions (Figure 3.2). Variation in fuel use for different housing types was examined by estimating separate equations for each of three housing types, mobile homes, single family homes, and multi-family units. 


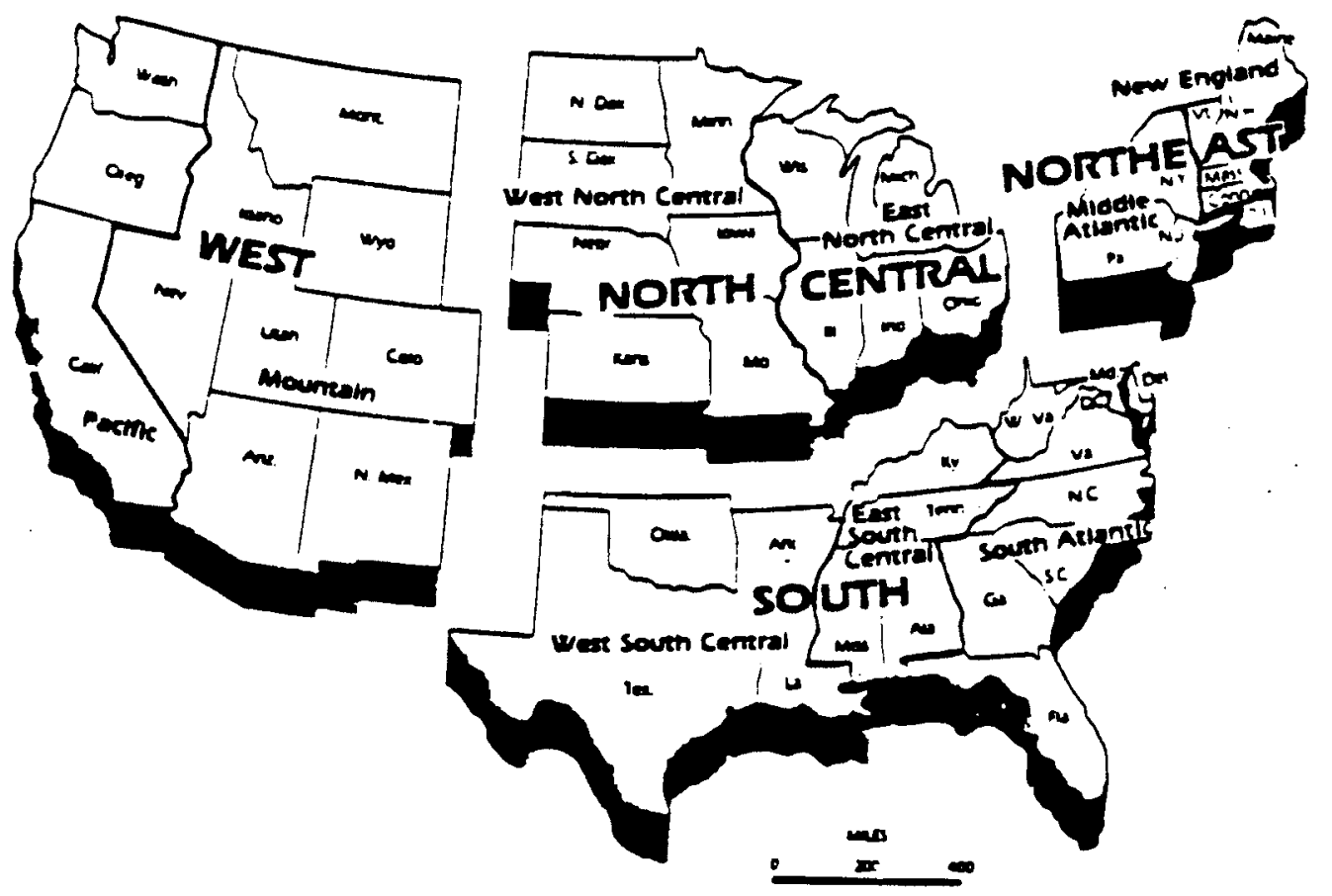

\section{Figure 3.2. Census Regions}

A widely-used technique known as conditional demand analysis was used to estimate equations for each of the three major residential fuels, oil, electricity, and gas (defined to include natural gas and liquified petroleum gas). A major premise of conditional demand analysis is that the stock of energy-using equipment existing in a household limits the ability of the household to change its use of a fuel. The technique essentially separates the household decision process into two components: First, the household chooses the fuel-using equipment (e.g. a gas furnace or an electric range). Once the equipment is chosen, the household chooses the intensity with which the equipment is used. In principle, this separates price and income responses 
into a short-term and long-term response for individual households. The shortterm response only affects variation in the intensity of use of the equipment while the full long-term response affects choice of household equipment and therefore fuel choice. In the aggregate, incremental stock adjustment, as older equipment is gradually replaced, leads to price responses intermediate to the discrete changes occurring at the individual level. (a)

Given the general methodology described above, it is necessary to determine variables for inclusion and the specific forms of variables. The basic method was to estimate an equation for each major fuel (gas, electricity, and oil), for each census region (Northeast, North Central, South, and West), and for each of three housing types (mobile home, buildings with less than 4 units, and buildings with five or more units), for a total of 36 equations. The same basic variables are included across region and housing type. Specific equations for fuels differ; variables included for each fuel are detailed in Tables 3.1 to 3.3. A group of explanatory variables are common to most appliance/technologies and fuels; these include the relevant fuel price, the number of people in the household, and household income.

The contribution of coal and renewable energy sources, primarily solar and wood, is reported as an offset to base case heating fuel use. Penetration of renewable heating technologies was estimated as a share of the heating equipment stock; the fuel contribution, measured in Btu's, was estimated as the fuel that would have been used if the households had heated with gas and the amount of fuel use was equal to gas use at the mean values of the exogenous variables. This approach was used in lieu of estimating renewable use directly for two primary reasons. First, RECS data on wood use and the price of wood or other renewables is poor. Second, technologies like solar heating have no fuel component and their contribution to U.S. energy supply is probably best captured by indicating the savings of conventional, commercial fuel represented by penetration of the technology.

(a) One implication of explicitly recognizing equipment vintage and technology/appliance choice over time is that the fuel shares in 1995 differ for different fuel price paths over time even if the two paths converged to the same set of prices in 1995. 
IABLE 3.1. Electricity Variables

Appliance/Iechnology

Explanatory Variables

Space conditioning

Electric (all primary elec. other than heat pump)

Floorspace; Heating

Degree Days; Year Constructed

Electric Heat Pump

Floorspace; Heating Degree Days; Cooling Degree Days; Year Constructed

Electric Central Air (other than heat pump)

Electric Window Air

Floorspace; Cooling

Degree Days; No. of

Window Units (for resi-

dences with window units);

Year Constructed

Hot Water Heating

Electric Hot Water Heater

Number of Household Members

Appliances

Refrigerator
Freezer
Clothes Dryer
Electric Range
Color TV
Pool

Number of Electric Appliances in the Household of Each Type;

Number of Household Members

other Uses

Common variables only

Common Variables

Average Price of Electricity; Household Income 
TABLE 3.2. Natural Gas Variables

Appli ance/Technology

Explanatory Variables

Space Conditioning

Gas Heat (all types other than heat Floorspace; Heating pump)

Gas Heat Pump

Degree Days

Floorspace; Heating

Degree Days; Cooling

Degree Days

Gas Air Conditioning

pump)

Floorspace; Cooling

Degree Days

Hot Water Heating

Gas Hot Water Heater

Number of Household Members

Appliances

Gas Range
Gas Clothes Dryer
Gas Refrigerator
Gas Freezer

Other Uses

Number of Gas Appliances in the Household of Each Type;

Number of Household Members

Common variables only

Common Variables

Average Price of Gas; Household Income 
IABLE 3.3 Fuel oil Variables

Appliance/Technology

Space Conditioning

011 Heat (a11 types)

Hot Water Heating

011 Hot Water Heater

Other Uses

Common Variables
Explanatory Variables

Floorspace; Heating

Degree Days

Number of Household Members

Common variables only

Price of Fuel 011; Household Income 


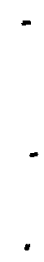




\subsection{PROJECTED FUEL SHARES AND SENSITIVITY ANALYSIS}

This section reports base case projections to 1995 and briefly reviews the assumptions used to develop the base case. In addition to the base projections, sensitivity scenarios were computed for each of seven factors potentially having an impact on residential fuel shares between now and 1995. The factors examined are household size, Snow Belt to Sun Belt migration, electricity prices, 011 prices, gas prices, personal income, and technology penetration.

\subsection{Base Case Assumptions}

The primary assumptions needed to generate a fuel share scenario are the number of households, household size, family income, and fuel prices. Each of these variables are disaggregated by region, housing type, fuel, and technology. The general assumption, unless otherwise specified, is that mean values of each disaggregated variable increase (decrease) at the same rate as the national variable. The assumed changes in the aggregate variables between 1981 and 1995 are given in Table 4.1. Values from 1981 to the present are actual values when available and for future years are interpolations from the present to the value given for 1995 .

The values in Table 4.1 reflect fairly standard assumptions for these major exogenous assumptions. Household income shows only an 8.9 percent increase between 1981 and 1995 reflecting strong growth in GNP but an income shift to other GNP components. Number of households by region reflects a continuing shift of the population toward the South and West. The number of persons per household (household size) is assumed to be unchanged.

Fuel price changes are based on recent DRI forecasts as reported in Table 4.1 and reflect recent drops in the price of oil and other fuels. The specific pattern of fuel price changes is shown in. Figure 4.1 . 
TABLE 4.1. Future Values of Exogenous Assumptions

\begin{tabular}{|c|c|c|}
\hline Variables (a) & $\begin{array}{l}\text { Percent } \\
\text { Change } \\
1981-95 \\
\end{array}$ & Comments \\
\hline Household Income & 8.9 & $\begin{array}{l}\text { Household income growth of } 2.6 \% \text { (real) } \\
\text { average yearly growth in GNP. Disposable } \\
\text { income divided by number of househo- } \\
\text { lds (b), 1981-85(c), 1981-85 projected (d). }\end{array}$ \\
\hline $\begin{array}{l}\text { Number of Households } \\
\text { North East (NE) } \\
\text { North Central (NC) } \\
\text { South (S) } \\
\text { West (W) }\end{array}$ & $\begin{array}{l}12.3 \\
19.4 \\
37.5 \\
47.2\end{array}$ & $\begin{array}{l}\text { Assumes households increase nationwide } \\
\text { by } 29.5 \% \text {. Regional shares change as } \\
\text { follows: NE, } 21 \% \text { (' } 81 \text { ) to } 18 \%(' 95) \text {; } \\
\text { NC, } 25 \%(81 \%) \text { to } 23 \% \text { ('95); S, } 34 \% \\
\text { (' } 81) \text { to } 36 \% \text { ('95); W, } 20 \% \text { (' } 81 \% \text { ) to } \\
22 \% \text { ('95). A11 household types assumed } \\
\text { to increase proportionally within } \\
\text { region. (d) }\end{array}$ \\
\hline Fuel oil Price & -41.1 & $\begin{array}{l}\text { Collapse of oil prices in ' } 86, \text { gradual } \\
\text { recovery in 1990s. 1981-85(c), 1986-95 } \\
\text { projected(c) }\end{array}$ \\
\hline Gas Price & 14.5 & $1981-85(e), 1986-95$ projected (d). \\
\hline Electricity Price & -27.8 & Same as above \\
\hline Household Size & 0.0 & $(f)$ \\
\hline
\end{tabular}

(a) All variables except number of households assumed to be the same for all regions and housing types.

(b) Based on data in U.S. Department of Commerce. 1984. Statistical Abstract of the United States: 1985. Washington, D.C., p. 10.

(c) Based on figures from February 1986 Economic Report of the President, U.S. Government Printing Office. Washington, D.C.

(d) Based on trend projections from Data Resources, Inc. (Spring 1986). U.S. Long Term Review.

(e) Based on projections from the Energy Information Administration (1984). Annual Energy Outlook, U. S. Government Printing Office. Washington, D.C.

(f) For a discussion of future trends in household size, see Bogue, Donald J., 1985. The Population of the United States: Historical Trends and Future Projections. The Free Press. New York. 


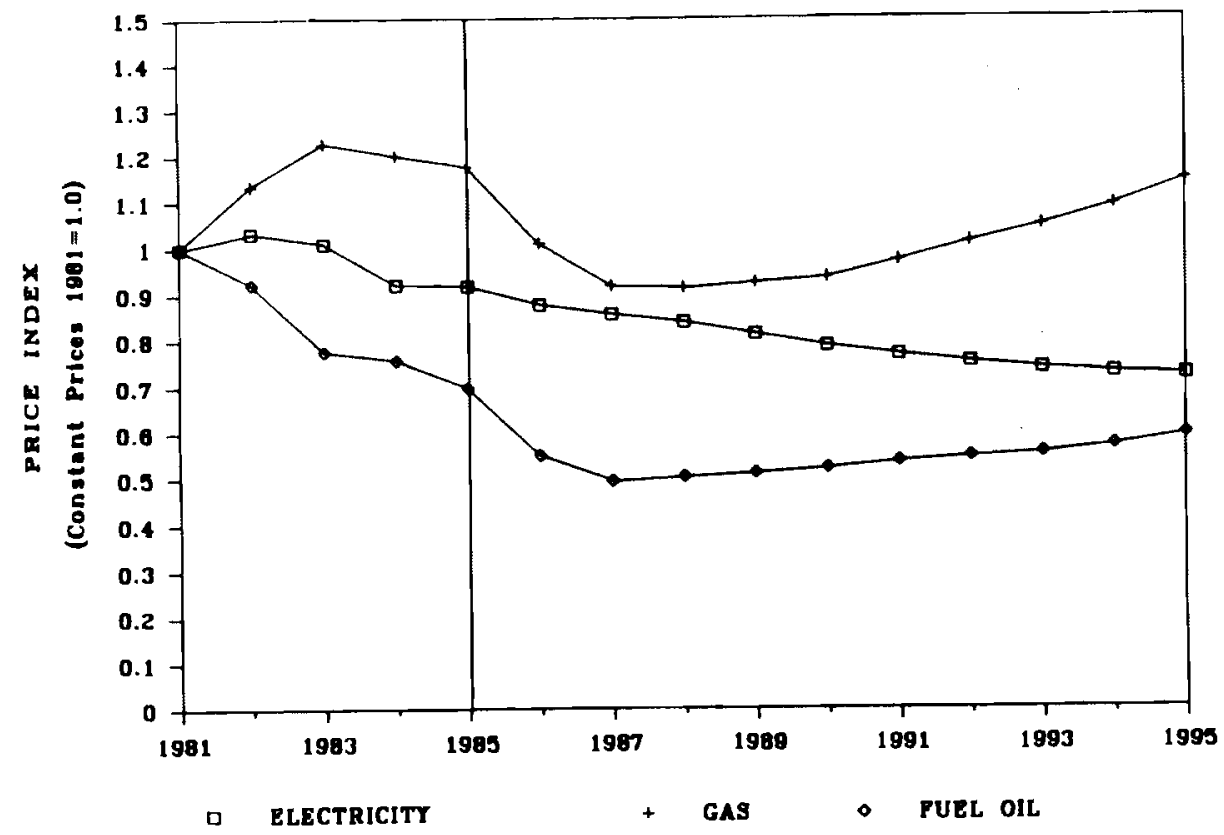

Eigure 4.1. Base Case Fuel Price Assumptions

\subsection{Base Case Results}

Figure 4.2 depicts changing residential fuel shares, including the historical period, 1960-1984, and projections for 1984-1995. Electricity is reported here and throughout this report as the heat value of purchased electricity. (a) The most dramatic change occurs in the electricity share due to penetration of the electric heat pump. The ofl share continues

(a) Some would argue that this reporting understates the "contribution" of electricity. In general, the comparability of electricity to other forms of energy is problematic. Since two-thirds of the energy in coal, oil, or nuclear heat is lost in conversion to electricity, the purchased electricity accounting convention severely understates the primary demand for fuels implied by electricity use. At the same time, electricity is much more efficient in providing mechanical drive and light. If these services were supplied by oil or gas in the household many more Btu's would be required to produce an equivalent level of service. The electric heat pump is a prime example of the problems of comparability: electricity is used to pump heat rather than produce heat. Thus, the amount of heating service supplied to a household in BTU's is actually greater than the Btu's of electricity used implying an "efficiency" greater than one. This is impossible for conventional gas or oil heat (or for electric resistance heating) where the energy in the fuel is used to produce heat and is subject to losses. 


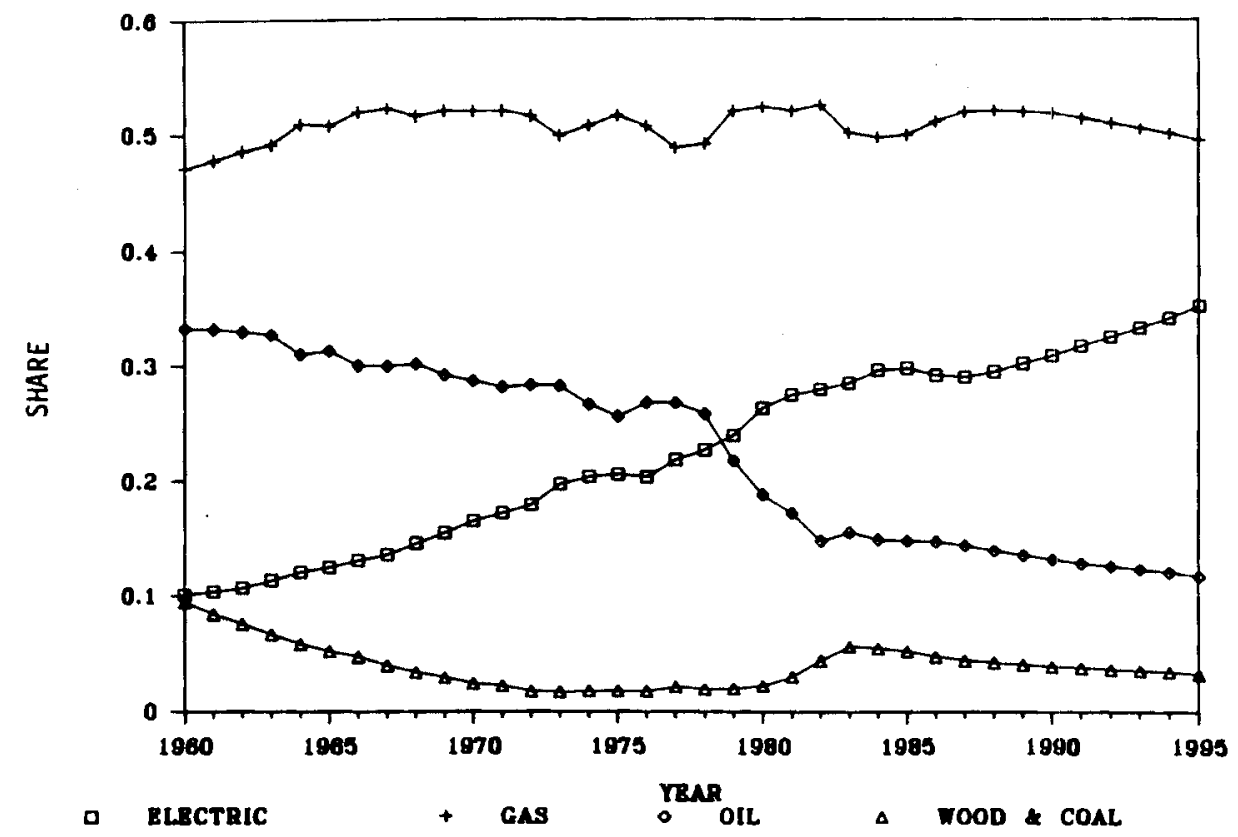

Figure 4.2. Historical and Projected Fuel Shares

to decline because oil heating continues to be phased out; i.e. few homes are assumed to be constructed or retrofitted with oil heating equipment. While the oil share is projected to continue falling, the drop is not nearly as rapid as the drop experienced between 1978 and 1982, reflecting the impact of projected low and falling oil prices. The natural gas share falls gradually between 1986 and 1995 largely reflecting the increase in gas prices relative to other fuels.

Wood, coal, and renewable energy sources, after increasing greatly during the early 1980's; show a slight decrease between 1986 and 1995 reflecting the general low and falling price of commercial energy. The small change in the gas share reflects a combination of further penetration of gas heat but also price-induced conservation in households with gas. Table 4.2 provides fuel and aggregate energy use on which the Figure 4.2 is based.

\subsection{SENSITIVITY OF RESULTS TO CHANGES IN ASSUMPTIONS}

Underlying any forecast are various assumptions some of which strongly influence results. Exploration of the sensitivity of results to changes in assumptions can help to identify uncertainties in the forecast and identify areas that require additional investigation. There are various "sensitivity" 
techniques, each suitable for different purposes. Formal sensitivity analysis, in which each exogenous assumption is varied and changes in outputs noted, is best suited for complex models where numerous interactions among variables exist. This is because it is difficult to compute analytically responsiveness of complex models. Formal sensitivity analysis is used primarily as a

TABLE 4.2. Energy use In the Residential Sector by Fuel: 1960 to 1995 (QUADS)

(1982-1995 Projected)

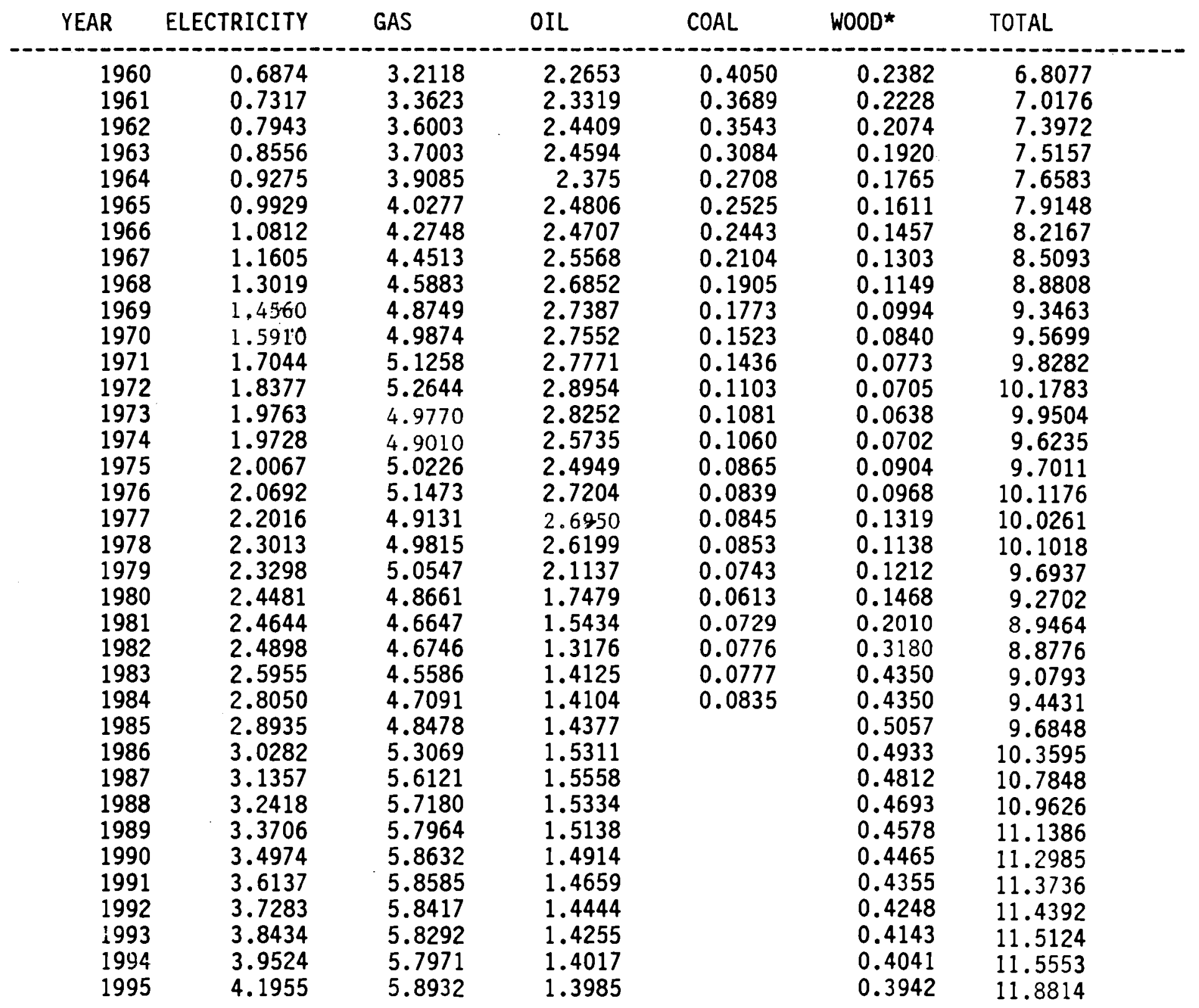

* Projections (1985-1995) combine coal and wood

$$
4.5
$$


diagnostic tool to understand these models. By contrast the equations used to compute fuel shares in this report are relatively simple and interaction among variables is minimal. Therefore, it was possible to compute analytically the model responsiveness.

A more general notion of sensitivity analysis would include exploring both the model responsiveness to changes in variables and the uncertainty in the assumptions. Formal techniques of this type are known as Monte Carlo analysis. In Monte Carlo analysis a range of values is selected for each exogenous assumption and parameter. The ranges are sampled and the results are simulated for each sample to form a distribution of outcomes. This approach has particular application for describing the full uncertainty associated with a forecast. It can also provide a ranking of parameters and exogenous assumptions based on the sensitivity of the model and the uncertainty in the parameter. Use of Monte Carlo techniques is appropriate when the model is nonlinear since the expected value result, except in the linear case, is not the same as the results derived from simulating the model using expected values for inputs. The equations used to simulate fuel use in this report are linear, thus the latter concern does not exist.

The sensitivity approach used in this study follows the spirit of Monte Carlo techniques by setting a meaningful (rather than arbitrary) range for exogenous assumptions. It is meant to illuminate the combined effect of the sensitivity of the model and the uncertainty in the assumptions. The model is simulated once for the high and once for the low value of each assumption, assuming all other variables remain at their base values. (a) In addition, the impact of various price shock scenarios are examined.

\subsection{The Outlook for Factors Affecting Fuel Shares}

The following exogenous assumptions were investigated: Snow Belt to Sun Belt migration, electricity prices, oil prices, gas prices, personal income, technology penetration, and non-price induced efficiency of heating/cooling technologies. This section briefly reviews the outlook for future (through

(a) This is not equivalent to Monte Carlo analysis as can be seen by a simple example. If in some cases no heat pumps existed, the responsiveness of electricity demand by heat pumps would obviously be zero in those cases. In a Monte Carlo analysis, this type of variable interaction would be included. In the type of analysis conducted here sensitivity of one variable is dependent on the particular value chosen for other variables. 
1995) value of these assumptions. To examine the sensitivity of future fuel shares to these factors the following scenarios were examined:

- High (Low) Fuel Price Cases

Sensitivity assumptions for high (low) fuel prices are based on linear increases (decreases) of between 0 and 25 percent ( -25 percent) of the 1986 to 1995 base price forecasts of gas, electricity and fuel oil.

- High (Low) Income Cases

Real disposable income per household was assumed to rise linearly (fall) from the base 1986 to 1995 case forecast of between 0 and 10 percent $(-10$ percent $)$.

- High (Low) Population Shift Cases

The population shift to the sunbelt states (represented by the South and West regions) was assumed to continue in the base case to where 57.8 percent of the population resided in the sunbelt states by 1995. The high (low) population shift case assumed that migration to the sunbelt states accelerated (slowed) to where in 1995, 61.8 percent (53.8 percent) of the U.S. population resided in the sunbelt states.

- Heat Pump Penetration Case

Time-driven penetration of electric heat pumps was increased such that, apart from fuel and equipment price effects, the market share of electric heat pumps increased from 15 percent in 1981 to 35 percent in 1995 compared to an increase to 18 percent in the base case by 1995 .

In all cases, actual values are used for the years 1981 (the model base year) to 1984 (latest available data).

\subsection{SENSITIVITY RESULTS}

Table 4.3 summarizes the impacts on fuel shares of the sensitivity scenarios given above. In general, fuel prices have the most significant impact on both share and quantity of fuels. As discussed previously, fuel prices affect both the intensity with which energy-using equipment is used and the choice among equipment using different fuels. Thus, a fuel price increase has an immediate conservation impact, reducing the use of the fuel but leaving the use of other fuels unaffected, and a long-term effect of decreasing the purchased share of equipment using the fuel. Because gas is the most prevalent fuel in the sector, a gas price increase has the most dramatic impact on fuel shares and fuel quantity. Similarly, the impact of electricity prices is significant because of the large share of electricity. 


\section{TABLE 4.3. Summary of Sensitivity Results}

(Impacts in 1995)

\begin{tabular}{lcc} 
Assumption & $\begin{array}{c}\text { Impact on } \\
\text { Share(a) }\end{array}$ & $\begin{array}{c}\text { Impact on } \\
\text { Quantity(b) }\end{array}$ \\
\cline { 2 - 2 } Gas Prices & 14.8 & 1.5385 \\
Electricity Prices & 9.8 & .6495 \\
Heat Pump Penetration & 6.3 & .3838 \\
Oil Prices & 3.6 & .2337 \\
Migration & 3.4 & .2488 \\
Income & .2 & .1734
\end{tabular}

(a) Measured as the sum of the absolute value in the share deviation between the high and low case.

(b) Measured as the aggregate energy use difference between the high and low cases in quads.

The percentage change in oil use resulting from an oil price change is on par with that for gas and electricity but because the share of oil dwindles to such a low level, the overall impact on fuel shares is smaller.

Penetration of electric heat pumps not explainable as part of the price response due to changing prices of electricity also has a significant effect. This result is not surprising because it directly substitutes electricity for gas and oil in space heating which is a major component of total residential energy demand. More rapid migration to the South and West has the expected effect of increasing the electricity share and decreasing overall fuel use. However, the effects are not nearly as strong as fuel prices. Income has very little impact on fuel shares and results in only a modest increase in fuel use.

Detailed results of the sensitivity analyses are provide in Tables 4.4 through 4.14 . 
IABLE 4.4. High Gas Prices

(QUADS)

\begin{tabular}{|c|c|c|c|c|c|}
\hline Years & $\begin{array}{c}\text { Total } \\
\text { Electricity }\end{array}$ & $\begin{array}{l}\text { Total } \\
\text { Gas }\end{array}$ & $\begin{array}{c}\text { Total } \\
011\end{array}$ & $\begin{array}{c}\text { Total } \\
\text { Wood \& Coal }\end{array}$ & $\begin{array}{l}\text { Total } \\
\text { Energy }\end{array}$ \\
\hline $\begin{array}{l}1981 \\
1982 \\
1983 \\
1984 \\
1985 \\
1986 \\
1987 \\
1988 \\
1989 \\
1990 \\
1991 \\
1992 \\
1993 \\
1994 \\
1995\end{array}$ & $\begin{array}{l}2.4644 \\
2.4898 \\
2.5955 \\
2.8050 \\
2.8935 \\
3.0288 \\
3.1376 \\
3.2457 \\
3.3773 \\
3.5075 \\
3.6278 \\
3.7469 \\
3.8673 \\
3.9821 \\
4.2358\end{array}$ & $\begin{array}{l}4.6647 \\
4.6746 \\
4.5586 \\
4.7091 \\
4.8478 \\
5.2487 \\
5.5031 \\
5.5510 \\
5.5649 \\
5.5642 \\
5.4797 \\
5.3753 \\
5.2696 \\
5.1344 \\
5.0840\end{array}$ & $\begin{array}{l}1.5434 \\
1.3176 \\
1.4125 \\
1.4104 \\
1.4377 \\
1.5313 \\
1.5564 \\
1.5346 \\
1.5157 \\
1.4940 \\
1.4694 \\
1.4488 \\
1.4309 \\
1.4080 \\
1.4066\end{array}$ & $\begin{array}{l}0.2739 \\
0.3956 \\
0.5127 \\
0.5185 \\
0.5057 \\
0.4933 \\
0.4812 \\
0.4693 \\
0.4578 \\
0.4465 \\
0.4355 \\
0.4248 \\
0.4143 \\
0.4041 \\
0.3942\end{array}$ & $\begin{array}{r}8.9464 \\
8.8776 \\
9.0793 \\
9.4431 \\
9.6848 \\
10.3021 \\
10.6784 \\
10.8006 \\
10.9157 \\
11.0123 \\
11.0124 \\
10.9959 \\
10.9821 \\
10.9286 \\
11.1206\end{array}$ \\
\hline & 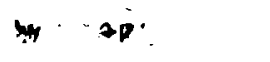 & & & & \\
\hline Years & $\begin{array}{c}\text { Total } \\
\text { Electricity }\end{array}$ & $\begin{array}{l}\text { Total } \\
\text { Gas }\end{array}$ & $\begin{array}{c}\text { Total } \\
011\end{array}$ & $\begin{array}{c}\text { Total } \\
\text { Wood \& Coal }\end{array}$ & $\begin{array}{l}\text { Total Residential } \\
\text { Energy Consumption }\end{array}$ \\
\hline $\begin{array}{l}1981 \\
1982 \\
1983 \\
1984 \\
1985 \\
1986 \\
1987 \\
1988 \\
1989 \\
1990 \\
1991 \\
1992 \\
1993 \\
1994 \\
1995\end{array}$ & $\begin{array}{l}27.5 \% \\
28.0 \% \\
28.6 \% \\
29.7 \% \\
29.9 \% \\
29.4 \% \\
29.4 \% \\
30.1 \% \\
30.9 \% \\
31.9 \% \\
32.9 \% \\
34.1 \% \\
35.2 \% \\
36.4 \% \\
38.1 \%\end{array}$ & $\begin{array}{l}52.1 \% \\
52.7 \% \\
50.2 \% \\
49.9 \% \\
50.1 \% \\
50.9 \% \\
51.5 \% \\
51.4 \% \\
51.0 \% \\
50.5 \% \\
49.8 \% \\
48.9 \% \\
48.0 \% \\
47.0 \% \\
45.7 \%\end{array}$ & $\begin{array}{l}17.39 \\
14.89 \\
15.69 \\
14.99 \\
14.89 \\
14.99 \\
14.69 \\
14.29 \\
13.99 \\
13.69 \\
13.39 \\
13.29 \\
13.09 \\
12.99 \\
12.69\end{array}$ & $\begin{array}{l}3.1 \% \\
4.5 \% \\
5.6 \% \\
5.5 \% \\
5.2 \% \\
4.8 \% \\
4.5 \% \\
4.3 \% \\
4.2 \% \\
4.1 \% \\
4.0 \% \\
3.9 \% \\
3.8 \% \\
3.7 \% \\
3.5 \%\end{array}$ & $\begin{array}{l}100.0 \% \\
100.0 \% \\
100.0 \% \\
100.0 \% \\
100.0 \% \\
100.0 \% \\
100.0 \% \\
100.0 \% \\
100.0 \% \\
100.0 \% \\
100.0 \% \\
100.0 \% \\
100.0 \% \\
100.0 \% \\
100.0 \%\end{array}$ \\
\hline
\end{tabular}


IABLE 4.5. Low Gas Prices

(QUADS)

\begin{tabular}{|c|c|c|c|c|c|}
\hline Years & $\begin{array}{c}\text { Total } \\
\text { Electricity }\end{array}$ & $\begin{array}{c}\text { Total } \\
\text { Gas }\end{array}$ & $\begin{array}{c}\text { Total } \\
011\end{array}$ & $\begin{array}{c}\text { Total } \\
\text { Wood \& Coal }\end{array}$ & $\begin{array}{l}\text { Total } \\
\text { Energy }\end{array}$ \\
\hline $\begin{array}{l}1981 \\
1982 \\
1983 \\
1984 \\
1985 \\
1986 \\
1987 \\
1988 \\
1989 \\
1990 \\
1991 \\
1992 \\
1993 \\
1994 \\
1995\end{array}$ & $\begin{array}{l}2.4644 \\
2.4898 \\
2.5955 \\
2.8050 \\
2.8935 \\
3.0275 \\
3.1336 \\
3.2376 \\
3.3634 \\
3.4864 \\
3.5981 \\
3.7071 \\
3.8157 \\
3.9172 \\
4.1463\end{array}$ & $\begin{array}{l}4.6647 \\
4.6746 \\
4.5586 \\
4.7091 \\
4.8478 \\
5.3652 \\
5.7214 \\
5.8859 \\
6.0296 \\
6.1654 \\
6.2425 \\
6.3164 \\
6.4009 \\
6.4771 \\
6.7300\end{array}$ & $\begin{array}{l}1.5434 \\
1.3176 \\
1.4125 \\
1.4104 \\
1.4377 \\
1.5309 \\
1.5552 \\
1.5322 \\
1.5118 \\
1.4884 \\
1.4620 \\
1.4394 \\
1.4193 \\
1.3942 \\
1.3887\end{array}$ & $\begin{array}{l}0.2739 \\
0.3956 \\
0.5127 \\
0.5185 \\
0.5057 \\
0.4933 \\
0.4812 \\
0.4693 \\
0.4578 \\
0.4465 \\
0.4355 \\
0.4248 \\
0.4143 \\
0.4041 \\
0.3942\end{array}$ & $\begin{array}{r}8.9464 \\
8.8776 \\
9.0793 \\
9.4431 \\
9.6848 \\
10.4170 \\
10.8914 \\
11.1250 \\
11.3625 \\
11.5867 \\
11.7381 \\
11.8877 \\
12.0502 \\
12.1927 \\
12.6591\end{array}$ \\
\hline
\end{tabular}

\begin{tabular}{|c|c|c|c|c|c|}
\hline Years & $\begin{array}{c}\text { Total } \\
\text { Electricity }\end{array}$ & $\begin{array}{l}\text { Total } \\
\text { Gas }\end{array}$ & $\begin{array}{c}\text { Total } \\
011\end{array}$ & $\begin{array}{c}\text { Total } \\
\text { Wood \& Coal }\end{array}$ & $\begin{array}{l}\text { Total Residential } \\
\text { Energy Consumption }\end{array}$ \\
\hline $\begin{array}{l}1981 \\
1982 \\
1983 \\
1984 \\
1985 \\
1986 \\
1987 \\
1988 \\
1989 \\
1990 \\
1991 \\
1992 \\
1993 \\
1994 \\
1995\end{array}$ & $\begin{array}{l}27.5 \% \\
28.0 \% \\
28.6 \% \\
29.7 \% \\
29.9 \% \\
29.1 \% \\
28.8 \% \\
29.1 \% \\
29.6 \% \\
30.1 \% \\
30.7 \% \\
31.2 \% \\
31.7 \% \\
32.1 \% \\
32.8 \%\end{array}$ & $\begin{array}{l}52.1 \% \\
52.7 \% \\
50.2 \% \\
49.9 \% \\
50.1 \% \\
51.5 \% \\
52.5 \% \\
52.9 \% \\
53.1 \% \\
53.2 \% \\
53.2 \% \\
53.1 \% \\
53.1 \% \\
53.1 \% \\
53.2 \%\end{array}$ & $\begin{array}{l}17.3 \% \\
14.8 \% \\
15.6 \% \\
14.9 \% \\
14.8 \% \\
14.7 \% \\
14.3 \% \\
13.8 \% \\
13.3 \% \\
12.8 \% \\
12.5 \% \\
12.1 \% \\
11.8 \% \\
11.4 \% \\
11.0 \%\end{array}$ & $\begin{array}{l}3.1 \% \\
4.5 \% \\
5.6 \% \\
5.5 \% \\
5.2 \% \\
4.7 \% \\
4.4 \% \\
4.2 \% \\
4.0 \% \\
3.9 \% \\
3.7 \% \\
3.6 \% \\
3.4 \% \\
3.3 \% \\
3.1 \%\end{array}$ & $\begin{array}{l}100.0 \% \\
100.0 \% \\
100.0 \% \\
100.0 \% \\
100.0 \% \\
100.0 \% \\
100.0 \% \\
100.0 \% \\
100.0 \% \\
100.0 \% \\
100.0 \% \\
100.0 \% \\
100.0 \% \\
100.0 \% \\
100.0 \%\end{array}$ \\
\hline
\end{tabular}


IABLE 4.6. High Electric Prices

(QUADS)

\begin{tabular}{|c|c|c|c|c|c|}
\hline Years & $\begin{array}{c}\text { Total } \\
\text { Electricity }\end{array}$ & $\begin{array}{c}\text { Total } \\
\text { Gas }\end{array}$ & $\begin{array}{c}\text { Total } \\
0 i 1\end{array}$ & $\begin{array}{c}\text { Total } \\
\text { Wood \& Coal }\end{array}$ & $\begin{array}{l}\text { Total } \\
\text { Energy }\end{array}$ \\
\hline $\begin{array}{l}1981 \\
1982 \\
1983 \\
1984 \\
1985 \\
1986 \\
1987 \\
1988 \\
1989 \\
1990 \\
1991 \\
1992 \\
1993 \\
1994 \\
1995\end{array}$ & $\begin{array}{l}2.4644 \\
2.4898 \\
2.5955 \\
2.8050 \\
2.8935 \\
2.9946 \\
3.0677 \\
3.1383 \\
3.2314 \\
3.3228 \\
3.4025 \\
3.4788 \\
3.5544 \\
3.6211 \\
3.8015\end{array}$ & $\begin{array}{l}4.6647 \\
4.6746 \\
4.5586 \\
4.7091 \\
4.8478 \\
5.3081 \\
5.6159 \\
5.7255 \\
5.8089 \\
5.8817 \\
5.8834 \\
5.8739 \\
5.8693 \\
5.8456 \\
5.9570\end{array}$ & $\begin{array}{l}1.5434 \\
1.3176 \\
1.4125 \\
1.4104 \\
1.4377 \\
1.5313 \\
1.5563 \\
1.5343 \\
1.5152 \\
1.4934 \\
1.4686 \\
1.4479 \\
1.4300 \\
1.4072 \\
1.4059\end{array}$ & $\begin{array}{l}0.2739 \\
0.3956 \\
0.5127 \\
0.5185 \\
0.5057 \\
0.4933 \\
0.4812 \\
0.4693 \\
0.4578 \\
0.4465 \\
0.4355 \\
0.4248 \\
0.4143 \\
0.4041 \\
0.3942\end{array}$ & $\begin{array}{r}8.9464 \\
8.8776 \\
9.0793 \\
9.4431 \\
9.6848 \\
10.3274 \\
10.7211 \\
10.8674 \\
11.0133 \\
11.1444 \\
11.1900 \\
11.2255 \\
11.2680 \\
11.2780 \\
11.5587\end{array}$ \\
\hline
\end{tabular}

\begin{tabular}{cccccc} 
Years & $\begin{array}{c}\text { Total } \\
\text { Electriclty }\end{array}$ & $\begin{array}{c}\text { Total } \\
\text { Gas }\end{array}$ & $\begin{array}{c}\text { Total } \\
\text { O1l }\end{array}$ & $\begin{array}{c}\text { Total } \\
\text { Wood \& Coal Energy Consumption }\end{array}$ \\
\hline 1981 & $27.5 \%$ & $52.1 \%$ & $17.3 \%$ & $3.1 \%$ & $100.0 \%$ \\
1982 & $28.0 \%$ & $52.7 \%$ & $14.8 \%$ & $4.5 \%$ & $100.0 \%$ \\
1983 & $28.6 \%$ & $50.2 \%$ & $15.6 \%$ & $5.6 \%$ & $100.0 \%$ \\
1984 & $29.7 \%$ & $49.9 \%$ & $14.9 \%$ & $5.5 \%$ & $100.0 \%$ \\
1985 & $29.9 \%$ & $50.1 \%$ & $14.8 \%$ & $5.2 \%$ & $100.0 \%$ \\
1986 & $29.0 \%$ & $51.4 \%$ & $14.8 \%$ & $4.8 \%$ & $100.0 \%$ \\
1987 & $28.6 \%$ & $52.4 \%$ & $14.5 \%$ & $4.5 \%$ & $100.0 \%$ \\
1988 & $28.9 \%$ & $52.7 \%$ & $14.1 \%$ & $4.3 \%$ & $100.0 \%$ \\
1989 & $29.3 \%$ & $52.7 \%$ & $13.8 \%$ & $4.2 \%$ & $100.0 \%$ \\
1990 & $29.8 \%$ & $52.8 \%$ & $13.4 \%$ & $4.0 \%$ & $100.0 \%$ \\
1991 & $30.4 \%$ & $52.6 \%$ & $13.1 \%$ & $3.9 \%$ & $100.0 \%$ \\
1992 & $31.0 \%$ & $52.3 \%$ & $12.9 \%$ & $3.8 \%$ & $100.0 \%$ \\
1993 & $31.5 \%$ & $52.1 \%$ & $12.7 \%$ & $3.7 \%$ & $100.0 \%$ \\
1994 & $32.1 \%$ & $51.8 \%$ & $12.5 \%$ & $3.6 \%$ & $100.0 \%$ \\
1995 & $32.9 \%$ & $51.5 \%$ & $12.2 \%$ & $3.4 \%$ & $100.0 \%$
\end{tabular}


IABLE 4.7. Low Electric Prices

(QUADS)

\begin{tabular}{|c|c|c|c|c|c|}
\hline Year & $\begin{array}{c}\text { Total } \\
\text { Electricity }\end{array}$ & $\begin{array}{l}\text { Total } \\
\text { Gas }\end{array}$ & $\begin{array}{c}\text { Total } \\
0 \text { il }\end{array}$ & $\begin{array}{l}\text { Total } \\
\text { Wood \& Coal }\end{array}$ & $\begin{array}{l}\text { Total Residential } \\
\text { Energy Consumption }\end{array}$ \\
\hline $\begin{array}{l}1981 \\
1982 \\
1983 \\
1984 \\
1985 \\
1986 \\
1987 \\
1988 \\
1989 \\
1990 \\
1991 \\
1992 \\
1993 \\
1994 \\
1995\end{array}$ & $\begin{array}{l}2.4644 \\
2.4898 \\
2.5955 \\
2.8050 \\
2.8935 \\
3.0617 \\
3.2039 \\
3.3460 \\
3.5114 \\
3.6749 \\
3.8297 \\
3.9848 \\
4.1426 \\
4.2981 \\
4.6116\end{array}$ & $\begin{array}{l}4.6647 \\
4.6746 \\
4.5586 \\
4.7091 \\
4.8478 \\
5.3057 \\
5.6082 \\
5.7100 \\
5.7827 \\
5.8425 \\
5.8299 \\
5.8041 \\
5.7812 \\
5.7379 \\
5.8131\end{array}$ & $\begin{array}{l}1.5434 \\
1.3176 \\
1.4125 \\
1.4104 \\
1.4377 \\
1.5310 \\
1.5554 \\
1.5325 \\
1.5123 \\
1.4891 \\
1.4628 \\
1.4403 \\
1.4202 \\
1.3951 \\
1.3894\end{array}$ & $\begin{array}{l}0.2739 \\
0.3956 \\
0.5127 \\
0.5185 \\
0.5057 \\
0.4933 \\
0.4812 \\
0.4693 \\
0.4578 \\
0.4465 \\
0.4355 \\
0.4248 \\
0.4143 \\
0.4041 \\
0.3942\end{array}$ & $\begin{array}{r}8.9464 \\
8.8776 \\
9.0793 \\
9.4431 \\
9.6848 \\
10.3917 \\
10.8486 \\
11.0578 \\
11.2641 \\
11.4530 \\
11.5579 \\
11.6540 \\
11.7584 \\
11.8352 \\
12.2082\end{array}$ \\
\hline
\end{tabular}

\begin{tabular}{|c|c|c|c|c|c|}
\hline Year & $\begin{array}{c}\text { Total } \\
\text { Electricity }\end{array}$ & $\begin{array}{l}\text { Total } \\
\text { Gas }\end{array}$ & $\begin{array}{l}\text { Total } \\
011\end{array}$ & $\begin{array}{c}\text { Total } \\
\text { Wood \& Coal }\end{array}$ & $\begin{array}{l}\text { Total Residential } \\
\text { Energy Consumption }\end{array}$ \\
\hline $\begin{array}{l}1981 \\
1982 \\
1983 \\
1984 \\
1985 \\
1986 \\
1987 \\
1988 \\
1989 \\
1990 \\
1991 \\
1992 \\
1993 \\
1994 \\
1995\end{array}$ & $\begin{array}{l}27.5 \% \\
28.0 \% \\
28.6 \% \\
29.7 \% \\
29.9 \% \\
29.5 \% \\
29.5 \% \\
30.3 \% \\
31.2 \% \\
32.1 \% \\
33.1 \% \\
34.2 \% \\
35.2 \% \\
36.3 \% \\
37.8 \%\end{array}$ & $\begin{array}{l}52.1 \% \\
52.7 \% \\
50.2 \% \\
49.9 \% \\
50.1 \% \\
51.1 \% \\
51.7 \% \\
51.6 \% \\
51.3 \% \\
51.0 \% \\
50.4 \% \\
49.8 \% \\
49.2 \% \\
48.5 \% \\
47.6 \%\end{array}$ & $\begin{array}{l}17.3 \% \\
14.8 \% \\
15.6 \% \\
14.9 \% \\
14.8 \% \\
14.7 \% \\
14.3 \% \\
13.9 \% \\
13.4 \% \\
13.0 \% \\
12.7 \% \\
12.4 \% \\
12.1 \% \\
11.8 \% \\
11.4 \%\end{array}$ & $\begin{array}{l}3.1 q \\
4.5 \% \\
5.6 \% \\
5.5 \% \\
5.2 \% \\
4.7 q \\
4.4 q \\
4.2 q \\
4.19 \\
3.9 q \\
3.8 q \\
3.6 q \\
3.5 q \\
3.49 \\
3.2 q\end{array}$ & $\begin{array}{l}100.0 \% \\
100.0 \% \\
100.0 \% \\
100.0 \% \\
100.0 \% \\
100.0 \% \\
100.0 \% \\
100.0 \% \\
100.0 \% \\
100.0 \% \\
100.0 \% \\
100.0 \% \\
100.0 \% \\
100.0 \% \\
100.0 \%\end{array}$ \\
\hline
\end{tabular}


IABLE 4.8. Heat Pump Penetration

(QUADS)

\begin{tabular}{|c|c|c|c|c|c|}
\hline Year & $\begin{array}{c}\text { Total } \\
\text { Electricity }\end{array}$ & $\begin{array}{c}\text { Total } \\
\text { Gas }\end{array}$ & $\begin{array}{c}\text { Total } \\
0 i 1\end{array}$ & $\begin{array}{c}\text { Total } \\
\text { Wood \& Coal }\end{array}$ & $\begin{array}{l}\text { Total Residential } \\
\text { Energy Consumption }\end{array}$ \\
\hline $\begin{array}{l}1981 \\
1982 \\
1983 \\
1984 \\
1985 \\
1986 \\
1987 \\
1988 \\
1989 \\
1990 \\
1991 \\
1992 \\
1993 \\
1994 \\
1995\end{array}$ & $\begin{array}{l}2.4644 \\
2.5739 \\
2.6963 \\
2.9313 \\
3.0438 \\
3.2065 \\
3.3433 \\
3.4805 \\
3.6446 \\
3.8072 \\
3.9593 \\
4.1104 \\
4.2629 \\
4.4093 \\
4.7205\end{array}$ & $\begin{array}{l}4.6647 \\
4.8158 \\
4.6842 \\
4.8227 \\
4.9456 \\
5.3924 \\
5.6780 \\
5.7590 \\
5.8098 \\
5.8489 \\
5.8166 \\
5.7725 \\
5.7329 \\
5.6746 \\
5.7271\end{array}$ & $\begin{array}{l}1.5434 \\
1.3587 \\
1.4556 \\
1.4523 \\
1.4790 \\
1.5735 \\
1.5971 \\
1.5725 \\
1.5507 \\
1.5262 \\
1.4987 \\
1.4753 \\
1.4545 \\
1.4289 \\
1.4234\end{array}$ & $\begin{array}{l}0.2739 \\
0.3956 \\
0.5127 \\
0.5185 \\
0.5057 \\
0.4933 \\
0.4812 \\
0.4693 \\
0.4578 \\
0.4465 \\
0.4355 \\
0.4248 \\
0.4143 \\
0.4041 \\
0.3942\end{array}$ & $\begin{array}{r}8.9464 \\
9.1441 \\
9.3487 \\
9.7247 \\
9.9741 \\
10.6657 \\
11.0996 \\
11.2814 \\
11.4629 \\
11.6288 \\
11.7101 \\
11.7829 \\
11.8646 \\
11.9169 \\
12.2652\end{array}$ \\
\hline
\end{tabular}

\begin{tabular}{|c|c|c|c|c|c|}
\hline Year & $\begin{array}{c}\text { Total } \\
\text { Electricity }\end{array}$ & $\begin{array}{l}\text { Total } \\
\text { Gas }\end{array}$ & $\begin{array}{c}\text { Total } \\
011\end{array}$ & $\begin{array}{c}\text { Total } \\
\text { Wood \& Coal }\end{array}$ & $\begin{array}{l}\text { Total Residential } \\
\text { Energy Consumption }\end{array}$ \\
\hline $\begin{array}{l}1981 \\
1982 \\
1983 \\
1984 \\
1985 \\
1986 \\
1987 \\
1988 \\
1989 \\
1990 \\
1991 \\
1992 \\
1993 \\
1994 \\
1995\end{array}$ & $\begin{array}{l}27.5 \% \\
28.1 \% \\
28.8 \% \\
30.1 \% \\
30.5 \% \\
30.1 \% \\
30.1 \% \\
30.9 \% \\
31.8 \% \\
32.7 \% \\
33.8 \% \\
34.9 \% \\
35.9 \% \\
37.0 \% \\
38.5 \%\end{array}$ & $\begin{array}{l}52.1 \% \\
52.7 \% \\
50.1 \% \\
49.6 \% \\
49.6 \% \\
50.6 \% \\
51.2 \% \\
51.0 \% \\
50.7 \% \\
50.3 \% \\
49.7 \% \\
49.0 \% \\
48.3 \% \\
47.6 \% \\
46.7 \%\end{array}$ & $\begin{array}{l}17.3 \% \\
14.9 \% \\
15.6 \% \\
14.9 \% \\
14.8 \% \\
14.8 \% \\
14.4 \% \\
13.9 \% \\
13.5 \% \\
13.1 \% \\
12.8 \% \\
12.5 \% \\
12.3 \% \\
12.0 \% \\
11.6 \%\end{array}$ & $\begin{array}{l}3.1 \% \\
4.3 \% \\
5.5 \% \\
5.3 \% \\
5.1 \% \\
4.6 \% \\
4.3 \% \\
4.2 \% \\
4.0 \% \\
3.8 \% \\
3.7 \% \\
3.6 \% \\
3.5 \% \\
3.4 \% \\
3.2 \%\end{array}$ & $\begin{array}{l}100.0 \% \\
100.0 \% \\
100.0 \% \\
100.0 \% \\
100.0 \% \\
100.0 \% \\
100.0 \% \\
100.0 \% \\
100.0 \% \\
100.0 \% \\
100.0 \% \\
100.0 \% \\
100.0 \% \\
100.0 \% \\
100.0 \%\end{array}$ \\
\hline
\end{tabular}


IABLE 4.9. High 0 il Prices

(QUADS)

\begin{tabular}{|c|c|c|c|c|c|}
\hline Years & $\begin{array}{c}\text { Total } \\
\text { Electricity }\end{array}$ & $\begin{array}{l}\text { Total } \\
\text { Gas }\end{array}$ & $\begin{array}{c}\text { Total } \\
011\end{array}$ & $\begin{array}{c}\text { Total } \\
\text { Wood \& Coal }\end{array}$ & $\begin{array}{l}\text { Total } \\
\text { Energy }\end{array}$ \\
\hline $\begin{array}{l}1981 \\
1982 \\
1983 \\
1984 \\
1985 \\
1986 \\
1987 \\
1988 \\
1989 \\
1990 \\
1991 \\
1992 \\
1993 \\
1994 \\
1995\end{array}$ & $\begin{array}{l}2.4644 \\
2.4898 \\
2.5955 \\
2.8050 \\
2.8935 \\
3.0282 \\
3.1357 \\
3.2419 \\
3.3708 \\
3.4977 \\
3.6141 \\
3.7288 \\
3.8440 \\
3.9531 \\
4.1964\end{array}$ & $\begin{array}{l}4.6647 \\
4.6746 \\
4.5586 \\
4.7091 \\
4.8478 \\
5.3071 \\
5.6125 \\
5.7188 \\
5.7976 \\
5.8649 \\
5.8606 \\
5.8443 \\
5.8322 \\
5.8006 \\
5.8975\end{array}$ & $\begin{array}{l}1.5434 \\
1.3176 \\
1.4125 \\
1.4104 \\
1.4377 \\
1.5205 \\
1.5364 \\
1.5036 \\
1.4733 \\
1.4396 \\
1.4023 \\
1.3690 \\
1.3384 \\
1.3014 \\
1.2798\end{array}$ & $\begin{array}{l}0.2739 \\
0.3956 \\
0.5127 \\
0.5185 \\
0.5057 \\
0.4933 \\
0.4812 \\
0.4693 \\
0.4578 \\
0.4465 \\
0.4355 \\
0.4248 \\
0.4143 \\
0.4041 \\
0.3942\end{array}$ & $\begin{array}{r}8.9464 \\
8.8776 \\
9.0793 \\
9.4431 \\
9.6848 \\
10.3491 \\
10.7659 \\
10.9337 \\
11.0994 \\
11.2487 \\
11.3125 \\
11.3669 \\
11.4289 \\
11.4593 \\
11.7680\end{array}$ \\
\hline
\end{tabular}

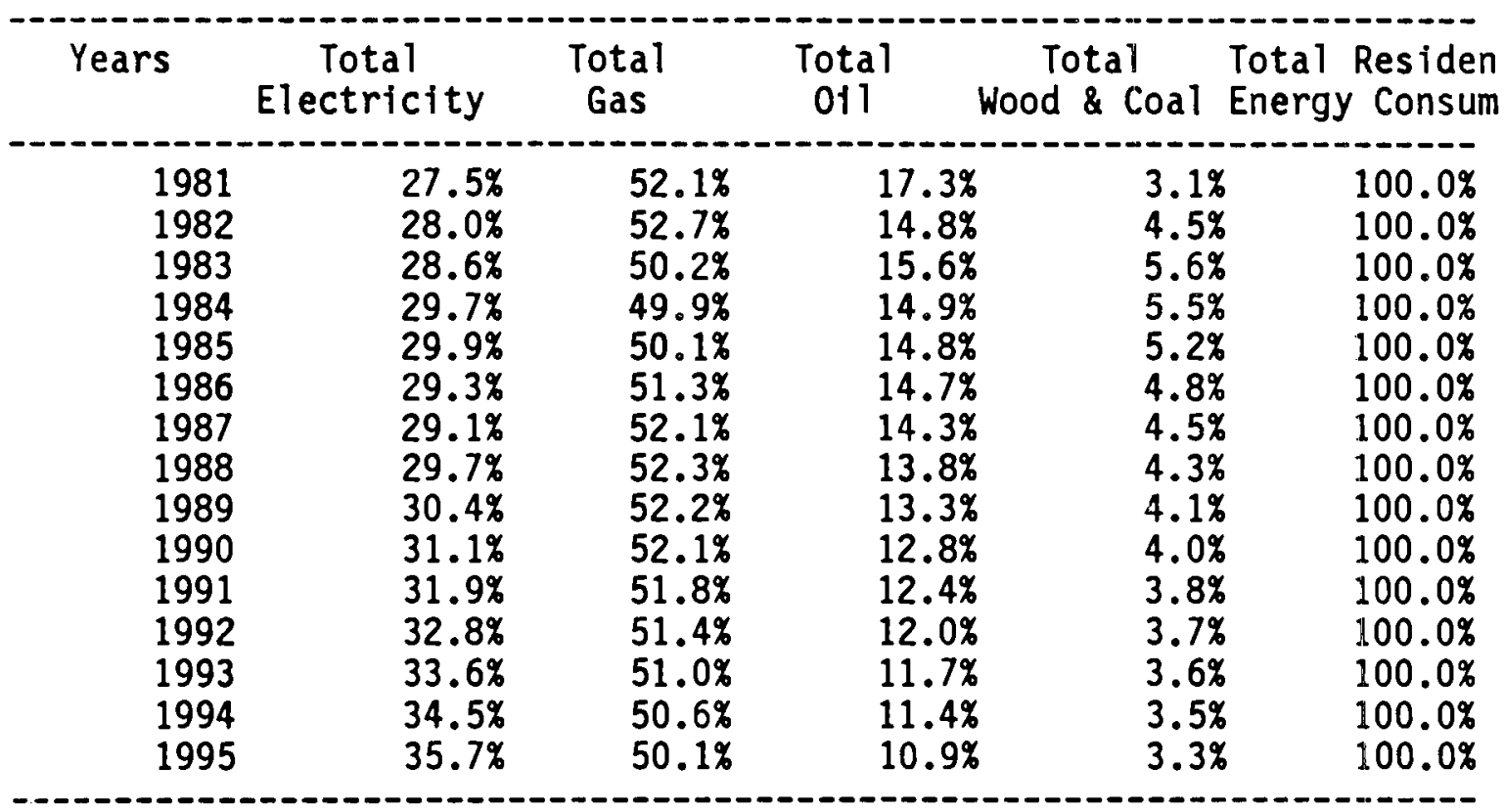


IABLE 4.10. Low 0 il Prices

(QUADS)

\begin{tabular}{|c|c|c|c|c|c|c|}
\hline Years & Years & $\begin{array}{c}\text { Total } \\
\text { Electricity }\end{array}$ & $\begin{array}{l}\text { Total } \\
\text { Gas }\end{array}$ & $\begin{array}{c}\text { Total } \\
011\end{array}$ & $\begin{array}{c}\text { Total } \\
\text { Wood \& Coal }\end{array}$ & $\begin{array}{l}\text { Total } \\
\text { Energy }\end{array}$ \\
\hline $\begin{array}{l}1981 \\
1982 \\
1983 \\
1984 \\
1985 \\
1986 \\
1987 \\
1988 \\
1989 \\
1990 \\
1991 \\
1992 \\
1993 \\
1994 \\
1995\end{array}$ & $\begin{array}{l}1981 \\
1982 \\
1983 \\
1984 \\
1985 \\
1986 \\
1987 \\
1988 \\
1989 \\
1990 \\
1991 \\
1992 \\
1993 \\
1994 \\
1995\end{array}$ & $\begin{array}{l}2.4644 \\
2.4898 \\
2.5955 \\
2.8050 \\
2.8935 \\
3.0281 \\
3.1356 \\
3.2417 \\
3.3704 \\
3.4971 \\
3.6133 \\
3.7277 \\
3.8426 \\
3.9514 \\
4.1941\end{array}$ & $\begin{array}{l}4.6647 \\
4.6746 \\
4.5586 \\
4.7091 \\
4.8478 \\
5.3068 \\
5.6117 \\
5.7172 \\
5.7951 \\
5.8613 \\
5.8559 \\
5.8385 \\
5.8252 \\
5.7924 \\
5.8871\end{array}$ & $\begin{array}{l}1.5434 \\
1.3176 \\
1.4125 \\
1.4104 \\
1.4377 \\
1.5418 \\
1.5753 \\
1.5635 \\
1.5550 \\
1.5443 \\
1.5314 \\
1.5227 \\
1.5168 \\
1.5078 \\
1.5263\end{array}$ & $\begin{array}{l}0.2739 \\
0.3956 \\
0.5127 \\
0.5185 \\
0.5057 \\
0.4933 \\
0.4812 \\
0.4693 \\
0.4578 \\
0.4465 \\
0.4355 \\
0.4248 \\
0.4143 \\
0.4041 \\
0.3942\end{array}$ & $\begin{array}{r}8.9464 \\
8.8776 \\
9.0793 \\
9.4431 \\
9.6848 \\
10.3700 \\
10.8038 \\
10.9917 \\
11.1782 \\
11.3492 \\
11.4361 \\
11.5137 \\
11.5990 \\
11.6557 \\
12.0017\end{array}$ \\
\hline
\end{tabular}

$\begin{array}{ccccccc}\text { Years } & \text { Years } & \begin{array}{c}\text { Total } \\ \text { Electricity }\end{array} & \begin{array}{c}\text { Total } \\ \text { Gas }\end{array} & \begin{array}{c}\text { Total } \\ \text { O11 }\end{array} & \begin{array}{c}\text { Total Wood \& Coal Energy Consumpt } \\ \text { Wotal Resident }\end{array} \\ 1981 & 1981 & 27.5 \% & 52.1 \% & 17.3 \% & 3.1 \% & 100.0 \% \\ 1982 & 1982 & 28.0 \% & 52.7 \% & 14.8 \% & 4.5 \% & 100.0 \% \\ 1983 & 1983 & 28.6 \% & 50.2 \% & 15.6 \% & 5.6 \% & 100.0 \% \\ 1984 & 1984 & 29.7 \% & 49.9 \% & 14.9 \% & 5.5 \% & 100.0 \% \\ 1985 & 1985 & 29.9 \% & 50.1 \% & 14.8 \% & 5.2 \% & 100.0 \% \\ 1986 & 1986 & 29.2 \% & 51.2 \% & 14.9 \% & 4.8 \% & 100.0 \% \\ 1987 & 1987 & 29.0 \% & 51.9 \% & 14.6 \% & 4.5 \% & 100.0 \% \\ 1988 & 1988 & 29.5 \% & 52.0 \% & 14.2 \% & 4.3 \% & 100.0 \% \\ 1989 & 1989 & 30.2 \% & 51.8 \% & 13.9 \% & 4.1 \% & 100.0 \% \\ 1990 & 1990 & 30.8 \% & 51.6 \% & 13.6 \% & 3.9 \% & 100.0 \% \\ 1991 & 1991 & 31.6 \% & 51.2 \% & 13.4 \% & 3.8 \% & 100.0 \% \\ 1992 & 1992 & 32.4 \% & 50.7 \% & 13.2 \% & 3.7 \% & 100.0 \% \\ 1993 & 1993 & 33.1 \% & 50.2 \% & 13.1 \% & 3.6 \% & 100.0 \% \\ 1994 & 1994 & 33.9 \% & 49.7 \% & 12.9 \% & 3.5 \% & 100.0 \% \\ 1995 & 1995 & 34.9 \% & 49.1 \% & 12.7 \% & 3.3 \% & 100.0 \%\end{array}$


IABLE 4.1.7. High Migration to the South and West (QUADS)

\begin{tabular}{|c|c|c|c|c|c|}
\hline Year & $\begin{array}{l}\text { Total } \\
\text { Electricity }\end{array}$ & $\begin{array}{l}\text { Total } \\
\text { Gas }\end{array}$ & $\begin{array}{c}\text { Total } \\
\text { 0il }\end{array}$ & $\begin{array}{l}\text { Total } \\
\text { Wood \& Coal }\end{array}$ & $\begin{array}{l}\text { Total Residential } \\
\text { Energy Consumption }\end{array}$ \\
\hline $\begin{array}{l}1981 \\
1982 \\
1983 \\
1984 \\
1985 \\
1986 \\
1987 \\
1988 \\
1989 \\
1990 \\
1991 \\
1992 \\
1993 \\
1994 \\
1995\end{array}$ & $\begin{array}{l}2.4644 \\
2.4898 \\
2.5955 \\
2.8050 \\
2.8935 \\
3.0320 \\
3.1436 \\
3.2540 \\
3.3875 \\
3.5192 \\
3.6406 \\
3.7603 \\
3.8807 \\
3.9952 \\
4.2456\end{array}$ & $\begin{array}{l}4.6647 \\
4.6746 \\
4.5586 \\
4.7091 \\
4.8478 \\
5.2948 \\
5.5861 \\
5.6781 \\
5.7425 \\
5.7953 \\
5.7774 \\
5.7481 \\
5.7232 \\
5.6795 \\
5.7616\end{array}$ & $\begin{array}{l}1.5434 \\
1.3176 \\
1.4125 \\
1.4104 \\
1.4377 \\
1.5271 \\
1.5475 \\
1.5209 \\
1.4971 \\
1.4704 \\
1.4408 \\
1.4151 \\
1.3920 \\
1.3641 \\
1.3556\end{array}$ & $\begin{array}{l}0.2739 \\
0.3956 \\
0.5127 \\
0.5185 \\
0.5057 \\
0.4933 \\
0.4812 \\
0.4693 \\
0.4578 \\
0.4465 \\
0.4355 \\
0.4248 \\
0.4143 \\
0.4041 \\
0.3942\end{array}$ & $\begin{array}{r}8.9464 \\
8.8776 \\
9.0793 \\
9.4431 \\
9.6848 \\
10.3471 \\
10.7583 \\
10.9223 \\
11.0848 \\
11.2314 \\
11.2943 \\
11.3483 \\
11.4103 \\
11.4429 \\
11.7570\end{array}$ \\
\hline & ! & & & & \\
\hline Year & $\begin{array}{c}\text { Total } \\
\text { Electricity }\end{array}$ & $\begin{array}{l}\text { Total } \\
\text { Gas }\end{array}$ & $\begin{array}{c}\text { Total } \\
011\end{array}$ & $\begin{array}{l}\text { Total } \\
\text { Wood \& Coal }\end{array}$ & $\begin{array}{l}\text { Total Residential } \\
\text { Energy Consumption }\end{array}$ \\
\hline $\begin{array}{l}1981 \\
1982 \\
1983 \\
1984 \\
1985 \\
1986 \\
1987 \\
1988 \\
1989 \\
1990 \\
1991 \\
1992 \\
1993 \\
1994 \\
1995\end{array}$ & $\begin{array}{l}27.5 \% \\
28.0 \% \\
28.6 \% \\
29.7 \% \\
29.9 \% \\
29.3 \% \\
29.2 \% \\
29.8 \% \\
30.6 \% \\
31.3 \% \\
32.2 \% \\
33.1 \% \\
34.0 \% \\
34.9 \% \\
36.1 \%\end{array}$ & $\begin{array}{l}52.1 \% \\
52.7 \% \\
50.2 \% \\
49.9 \% \\
50.1 \% \\
51.2 \% \\
51.9 \% \\
52.0 \% \\
51.8 \% \\
51.6 \% \\
51.2 \% \\
50.7 \% \\
50.2 \% \\
49.6 \% \\
49.0 \%\end{array}$ & $\begin{array}{l}17.3 \% \\
14.8 \% \\
15.6 \% \\
14.9 \% \\
14.8 \% \\
14.8 \% \\
14.4 \% \\
13.9 \% \\
13.5 \% \\
13.1 \% \\
12.8 \% \\
12.5 \% \\
12.2 \% \\
11.9 \% \\
11.5 \%\end{array}$ & $\begin{array}{l}3.19 \\
4.59 \\
5.69 \\
5.59 \\
5.29 \\
4.89 \\
4.5 \\
4.39 \\
4.19 \\
4.09 \\
3.99 \\
3.79 \\
3.69 \\
3.59 \\
3.49\end{array}$ & $\begin{array}{l}100.0 \% \\
100.0 \% \\
100.0 \% \\
100.0 \% \\
100.0 \% \\
100.0 \% \\
100.0 \% \\
100.0 \% \\
100.0 \% \\
100.0 \% \\
100.0 \% \\
100.0 \% \\
100.0 \% \\
100.0 \% \\
100.0 \%\end{array}$ \\
\hline
\end{tabular}


IABLE 4.12. Slow Migration to the South and West

(QUADS)

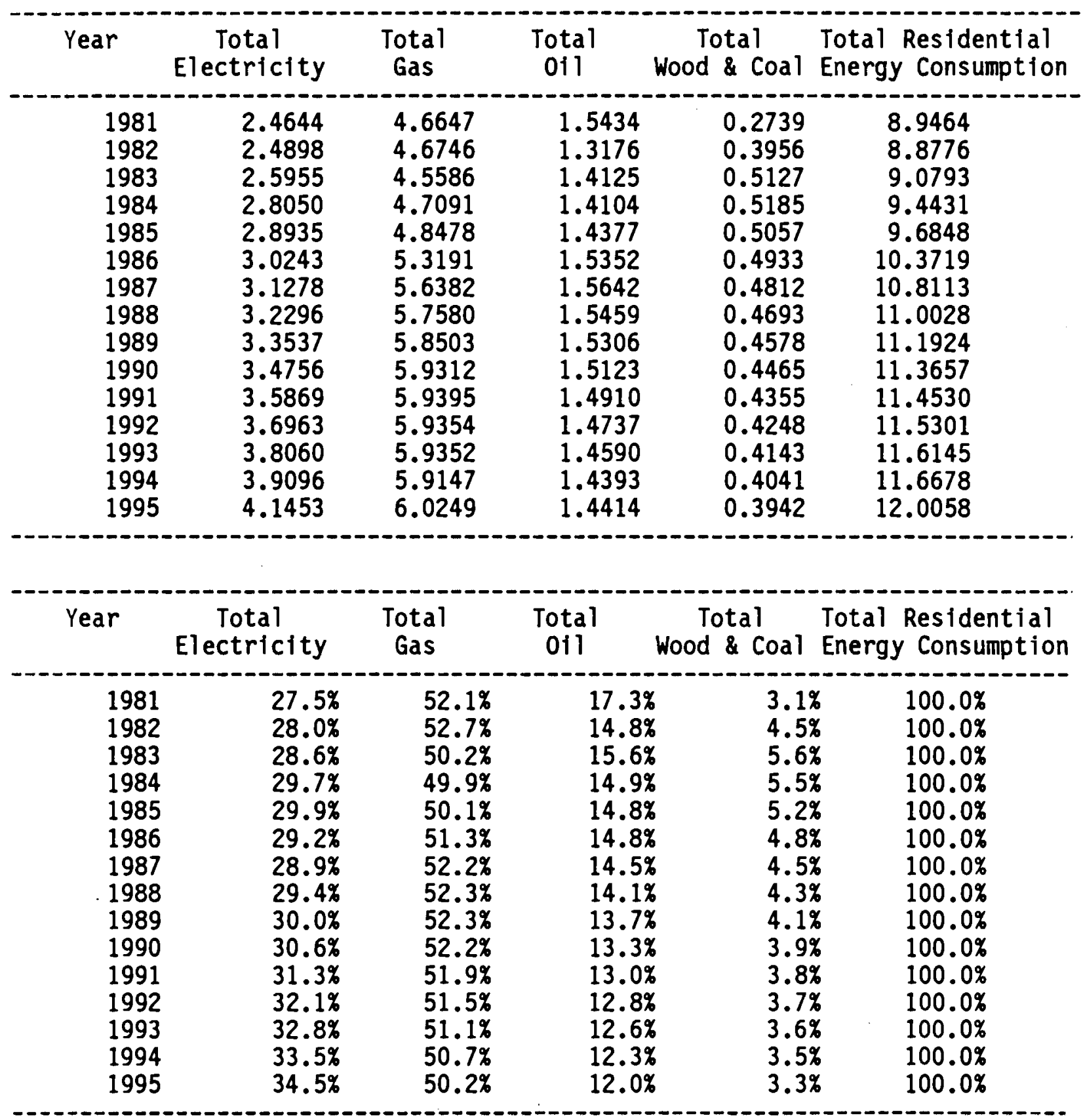


IABLE 4.13. High Income

(QUADS)

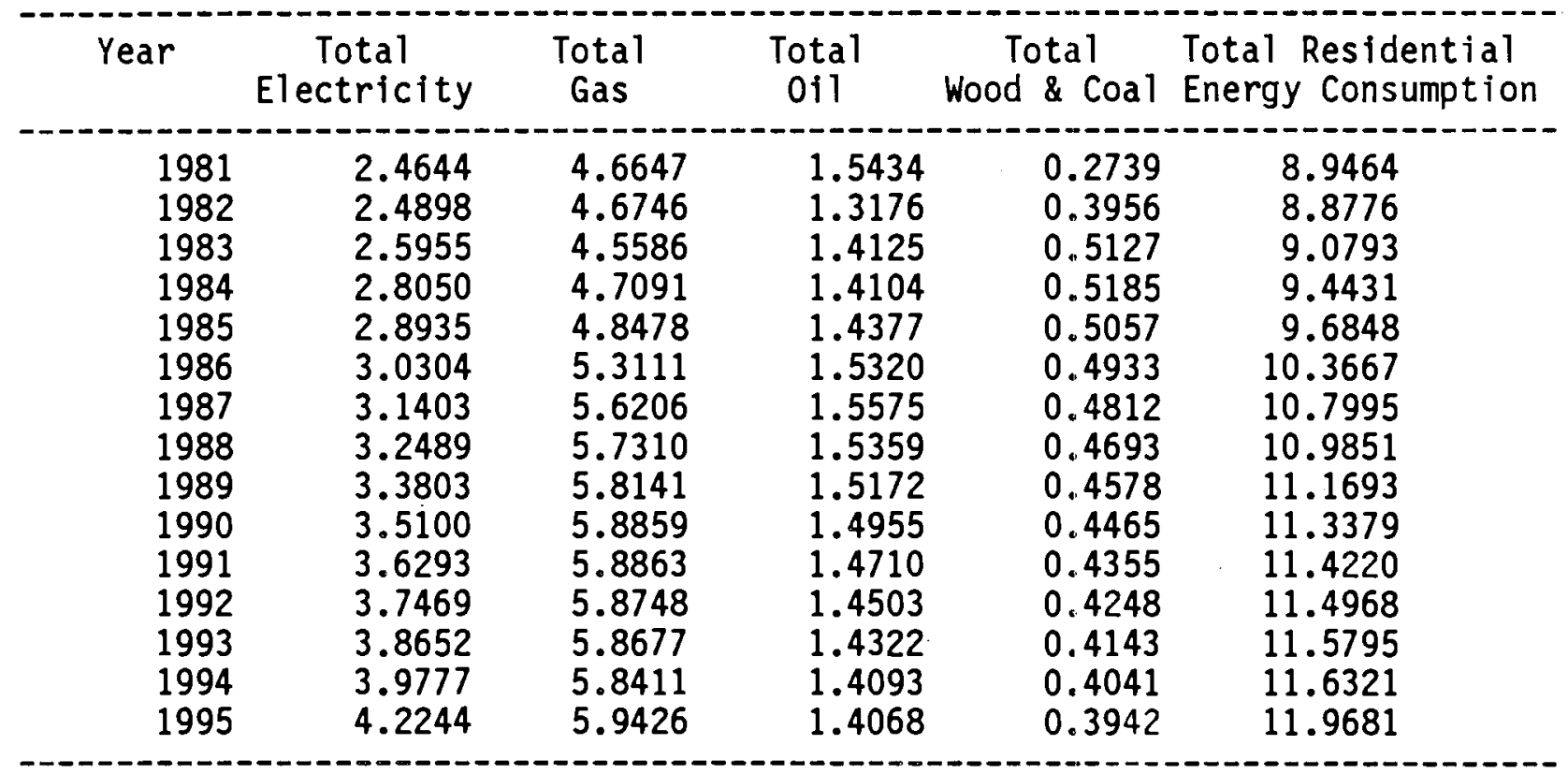

\begin{tabular}{cccccc} 
Year & $\begin{array}{c}\text { Total } \\
\text { Electricity }\end{array}$ & $\begin{array}{c}\text { Total } \\
\text { Gas }\end{array}$ & $\begin{array}{c}\text { Total } \\
\text { Oil }\end{array}$ & $\begin{array}{c}\text { Total } \\
\text { Wood \& Coal Energy Consumption }\end{array}$ \\
\hline 1981 & $27.5 \%$ & $52.1 \%$ & $17.3 \%$ & $3.1 \%$ & $100.0 \%$ \\
1982 & $28.0 \%$ & $52.7 \%$ & $14.8 \%$ & $4.5 \%$ & $100.0 \%$ \\
1983 & $28.6 \%$ & $50.2 \%$ & $15.6 \%$ & $5.6 \%$ & $100.0 \%$ \\
1984 & $29.7 \%$ & $49.9 \%$ & $14.9 \%$ & $5.5 \%$ & $100.0 \%$ \\
1985 & $29.9 \%$ & $50.1 \%$ & $14.8 \%$ & $5.2 \%$ & $100.0 \%$ \\
1986 & $29.2 \%$ & $51.2 \%$ & $14.8 \%$ & $4.8 \%$ & $100.0 \%$ \\
1987 & $29.1 \%$ & $52.0 \%$ & $14.4 \%$ & $4.5 \%$ & $100.0 \%$ \\
1988 & $29.6 \%$ & $52.2 \%$ & $14.0 \%$ & $4.3 \%$ & $100.0 \%$ \\
1989 & $30.3 \%$ & $52.1 \%$ & $13.6 \%$ & $4.1 \%$ & $100.0 \%$ \\
1990 & $31.0 \%$ & $51.9 \%$ & $13.2 \%$ & $3.9 \%$ & $100.0 \%$ \\
1991 & $31.8 \%$ & $51.5 \%$ & $12.9 \%$ & $3.8 \%$ & $100.0 \%$ \\
1992 & $32.6 \%$ & $51.1 \%$ & $12.6 \%$ & $3.7 \%$ & $100.0 \%$ \\
1993 & $33.4 \%$ & $50.7 \%$ & $12.4 \%$ & $3.6 \%$ & $100.0 \%$ \\
1994 & $34.2 \%$ & $50.2 \%$ & $12.1 \%$ & $3.5 \%$ & $100.0 \%$ \\
1995 & $35.3 \%$ & $49.7 \%$ & $11.8 \%$ & $3.3 \%$ & $100.0 \%$
\end{tabular}


IABLE 4.14. Low Income

(QUADS)

$\begin{array}{cccccc}\text { Year } & \begin{array}{c}\text { Total } \\ \text { Electricity }\end{array} & \begin{array}{c}\text { Total } \\ \text { Gas }\end{array} & \begin{array}{c}\text { Total } \\ \text { Oil }\end{array} & \begin{array}{c}\text { Total } \\ \text { Wood \& Coal }\end{array} \text { Total Residential } \\ \text { Energy Consumption }\end{array}$

\begin{tabular}{|c|c|c|c|c|c|}
\hline Year & $\begin{array}{l}\text { Total } \\
\text { Electricity }\end{array}$ & $\begin{array}{l}\text { Total } \\
\text { Gas }\end{array}$ & $\begin{array}{c}\text { Total } \\
\text { Oil }\end{array}$ & $\begin{array}{l}\text { Total } \\
\text { Wood \& Coal }\end{array}$ & $\begin{array}{l}\text { Total Residential } \\
\text { Energy Consumption }\end{array}$ \\
\hline $\begin{array}{l}1981 \\
1982 \\
1983 \\
1984 \\
1985 \\
1986 \\
1987 \\
1988 \\
1989 \\
1990 \\
1991 \\
1992 \\
1993 \\
1994 \\
1995\end{array}$ & $\begin{array}{l}27.5 \% \\
28.0 \% \\
28.6 \% \\
29.7 \% \\
29.9 \% \\
29.2 \% \\
29.1 \% \\
29.6 \% \\
30.3 \% \\
31.0 \% \\
31.8 \% \\
32.6 \% \\
33.4 \% \\
34.2 \% \\
35.3 \%\end{array}$ & $\begin{array}{l}52.1 \% \\
52.7 \% \\
50.2 \% \\
49.9 \% \\
50.1 \% \\
51.2 \% \\
52.0 \% \\
52.1 \% \\
52.0 \% \\
51.9 \% \\
51.5 \% \\
51.0 \% \\
50.6 \% \\
50.1 \% \\
49.5 \%\end{array}$ & $\begin{array}{l}17.3 \% \\
14.8 \% \\
15.6 \% \\
14.9 \% \\
14.8 \% \\
14.8 \% \\
14.4 \% \\
14.0 \% \\
13.6 \% \\
13.2 \% \\
12.9 \% \\
12.6 \% \\
12.4 \% \\
12.1 \% \\
11.8 \%\end{array}$ & $\begin{array}{l}3.1 \% \\
4.5 \% \\
5.6 \% \\
5.5 \% \\
5.2 \% \\
4.8 \% \\
4.5 \% \\
4.3 \% \\
4.1 \% \\
4.0 \% \\
3.8 \% \\
3.7 \% \\
3.6 \% \\
3.5 \% \\
3.3 \%\end{array}$ & $\begin{array}{l}100.0 \% \\
100.0 \% \\
100.0 \% \\
100.0 \% \\
100.0 \% \\
100.0 \% \\
100.0 \% \\
100.0 \% \\
100.0 \% \\
100.0 \% \\
100.0 \% \\
100.0 \% \\
100.0 \% \\
100.0 \% \\
100.0 \%\end{array}$ \\
\hline
\end{tabular}




\subsection{Scenario Analyses of Fue] Prices}

Fuel prices, particularly in the recent past, have been the most volatile of factors that affect fuel shares. In particular, oil price have been highly volatile having quadrupled and doubled during the 1970's, followed by a fall to one-third of the 1980 level by early 1986. Electricity prices have shown somewhat more stability than oil and gas prices, largely because of the heavy regulation of electricity rates by 50 separate state rate commissions, relatively high capital cost compared to fuel cost, and mix of fuels used to generate electricity. In addition, the typical pattern of fuel price increases in the past has been for at least oil and gas prices to move together and to a lesser extent for all prices to move together. Finally, there are some differences that exist in comparing brief price shocks with prolonged and gradual changes in prices. To explore these issues, the following scenarios were examined:

- Temporary 011 Price Shock Case

The 1987 forecast of fuel oil was based on the assumption of an average $\$ 15.88$ per barrel U.S. refiners' acquisition price (composite). In the temporary oil price shock case, the price of fuel oil was assumed to double from the base forecast in 1988, then linearly recover to the base forecast by 1995 as illustrated in Figure 4.3 .

- Prolonged 0il Price Shock Case

Assumptions are the same as the temporary oil price shock case except that prices do not recover and remain double the base price forecast for the entire 1988 to 1995 period as illustrated in Figure 4.3.

- High Electricity with Low Gas and 0il Prices Case Electricity prices are assumed to rise linearly from the 1986 to 1995 base forecast from 0 to 25 percent. Gas and oil prices are assumed to fall linearly from the base 1986 to 1995 forecast of between 0 and -25 percent.

- All High and All Low Prices

All prices are assumed to move together to generate an all high prices case and an all low prices case. Prices increase linearly to 25 percent above the base case and decrease to 25 percent below the base case by 1995 .

The results of these scenarios are given in Tables 4.15 through 4.19. The oil price shock cases have the expected effect of immediately and significantly reducing the share of oil from 14.4 to 10.9 percent. In the permanent price shock case, the oil share continues to decline to 8.2 percent 


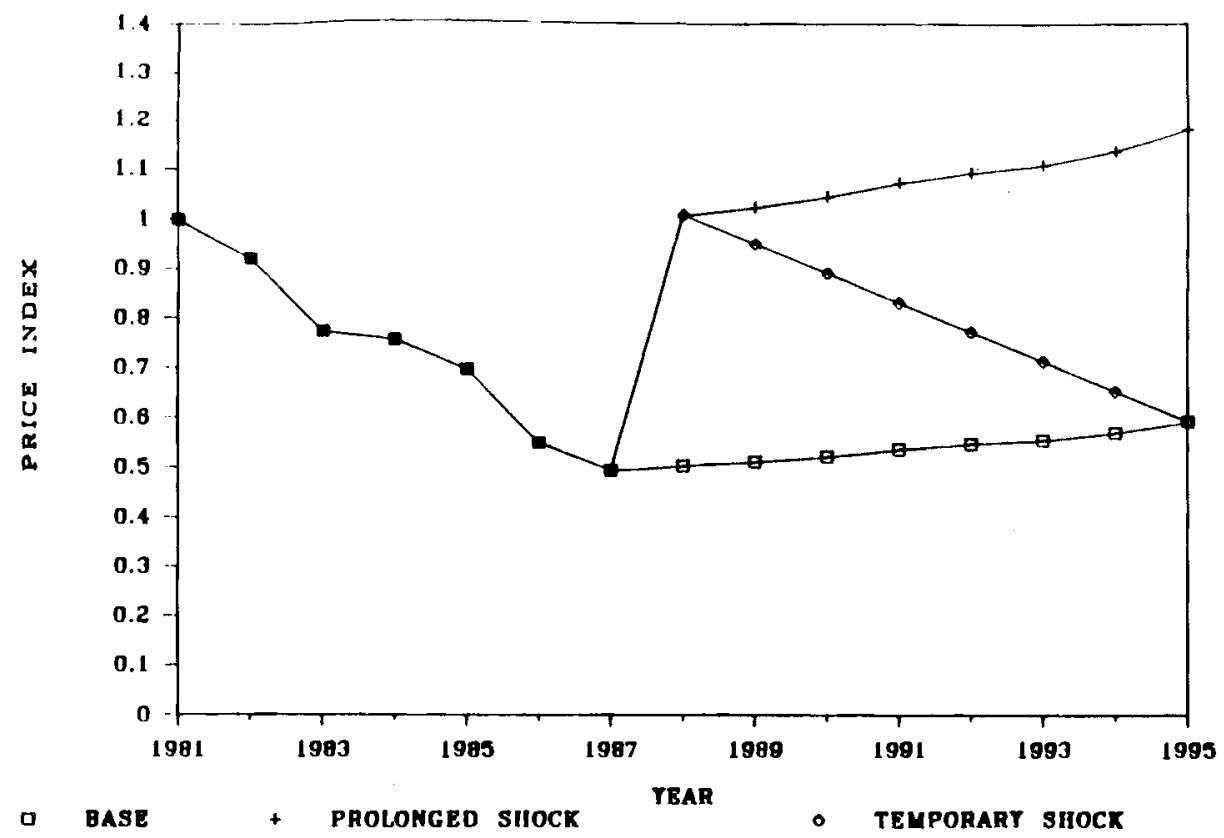

FIGURE 4.3. $0 i 1$ Price Shocks

by 1995 reflecting the accelerated replacement of oil furnaces with gas and electric heat. In contrast, the temporary price shock case has the oil price returning to the base case price by 1995 . The oil share recovers from the price shock years to 11.6 percent. This share remains below (though only slightly below) the 1995 base case share of 11.8 percent reflecting the fact that some households responded to the temporary oil price shock by replacing their oil furnaces. It is somewhat surprising that the difference between the base case and the temporary price shock is as small as it is. This is probably due to the fact that the model currently does not treat insulation and weather proofing as long-lived capital investments. Doing so would allow more realistic simulation of price shock phenomena.

The cases with all low and all high prices show generally expected results, the most important result being the 2.5 quad difference in aggregate fuel use. As might be expected, shares change less dramatically because all similar incentives to reduce (or increase) fuel use exist for all fuels. The final case considers high electric prices with falling oil and gas prices. The results show the gas share rising from the current (1985) 50.1 percent to 54.5 percent compared to a drop to 49.6 percent in the base case. The impact on electricity is to maintain the share essentially unchanged from 1985 at 30 percent compared to a steady increase to 35.3 percent in the base case. 
IABLE 4. 55. Temporary 0il Price Shock

(QUADS)

\begin{tabular}{|c|c|c|c|c|c|}
\hline Year & $\begin{array}{c}\text { Total } \\
\text { Electricity }\end{array}$ & $\begin{array}{c}\text { Total } \\
\text { Gas }\end{array}$ & $\begin{array}{c}\text { Total } \\
011\end{array}$ & $\begin{array}{c}\text { Total } \\
\text { Wood \& Coal }\end{array}$ & $\begin{array}{l}\text { Total Residential } \\
\text { Energy Consumption }\end{array}$ \\
\hline $\begin{array}{l}1981 \\
1982 \\
1983 \\
1984 \\
1985 \\
1986 \\
1987 \\
1988 \\
1989 \\
1990 \\
1991 \\
1992 \\
1993 \\
1994 \\
1995\end{array}$ & $\begin{array}{l}2.4644 \\
2.4898 \\
2.5955 \\
2.8050 \\
2.8935 \\
3.0282 \\
3.1357 \\
3.2422 \\
3.3714 \\
3.4986 \\
3.6152 \\
3.7299 \\
3.8451 \\
3.9542 \\
4.1972\end{array}$ & $\begin{array}{l}4.6647 \\
4.6746 \\
4.5586 \\
4.7091 \\
4.8478 \\
5.3069 \\
5.6121 \\
5.7208 \\
5.8015 \\
5.8701 \\
5.8665 \\
5.8504 \\
5.8382 \\
5.8059 \\
5.9014\end{array}$ & $\begin{array}{l}1.5434 \\
1.3176 \\
1.4125 \\
1.4104 \\
1.4377 \\
1.5311 \\
1.5558 \\
1.1577 \\
1.1844 \\
1.2104 \\
1.2361 \\
1.2622 \\
1.2892 \\
1.3171 \\
1.3717\end{array}$ & $\begin{array}{l}0.2739 \\
0.3956 \\
0.5127 \\
0.5185 \\
0.5057 \\
0.4933 \\
0.4812 \\
0.4693 \\
0.4578 \\
0.4465 \\
0.4355 \\
0.4248 \\
0.4143 \\
0.4041 \\
0.3942\end{array}$ & $\begin{array}{r}8.9464 \\
8.8776 \\
9.0793 \\
9.4431 \\
9.6848 \\
10.3595 \\
10.7848 \\
10.5900 \\
10.8151 \\
11.0256 \\
11.1532 \\
11.2673 \\
11.3868 \\
11.4814 \\
11.8645\end{array}$ \\
\hline Year & $\begin{array}{c}\text { Total } \\
\text { Electricity }\end{array}$ & $\begin{array}{c}\text { Total } \\
\text { Gas }\end{array}$ & $\begin{array}{c}\text { Total } \\
0 \text { il }\end{array}$ & $\begin{array}{c}\text { Total } \\
\text { Wood \& Coal }\end{array}$ & $\begin{array}{l}\text { Total Residential } \\
\text { Energy Consumption }\end{array}$ \\
\hline $\begin{array}{l}1981 \\
1982 \\
1983 \\
1984 \\
1985 \\
1986 \\
1987 \\
1988 \\
1989 \\
1990 \\
1991 \\
1992 \\
1993 \\
1994 \\
1995\end{array}$ & $\begin{array}{l}27.5 \% \\
28.0 \% \\
28.6 \% \\
29.7 \% \\
29.9 \% \\
29.2 \% \\
29.1 \% \\
30.6 \% \\
31.2 \% \\
31.7 \% \\
32.4 \% \\
33.1 \% \\
33.8 \% \\
34.4 \% \\
35.4 \%\end{array}$ & $\begin{array}{l}52.1 \% \\
52.7 \% \\
50.2 \% \\
49.9 \% \\
50.1 \% \\
51.2 \% \\
52.0 \% \\
54.0 \% \\
53.6 \% \\
53.2 \% \\
52.6 \% \\
51.9 \% \\
51.3 \% \\
50.6 \% \\
49.7 \%\end{array}$ & $\begin{array}{l}17.39 \\
14.89 \\
15.6 \% \\
14.9 \\
14.8 \\
14.8 \\
14.49 \\
10.9 \\
11.0 \\
11.0 \\
11.1 \\
11.2 \\
11.3 \\
11.5 \\
11.6\end{array}$ & $\begin{array}{l}3.1 \% \\
4.5 \% \\
5.6 \% \\
5.5 \% \\
5.2 \% \\
4.8 \% \\
4.5 \% \\
4.4 \% \\
4.2 \% \\
4.0 \% \\
3.9 q \\
3.8 \% \\
3.6 \% \\
3.5 \% \\
3.3 \%\end{array}$ & $\begin{array}{l}100.0 \% \\
100.0 \% \\
100.0 \% \\
100.0 \% \\
100.0 \% \\
100.0 \% \\
100.0 \% \\
100.0 \% \\
100.0 \% \\
100.0 \% \\
100.0 \% \\
100.0 \% \\
100.0 \% \\
100.0 \% \\
100.0 \%\end{array}$ \\
\hline
\end{tabular}


IABLE 4.16. Permanent 0 il Price Shock

(QUADS)

\begin{tabular}{|c|c|c|c|c|c|}
\hline Year & $\begin{array}{l}\text { Total } \\
\text { Electricity }\end{array}$ & $\begin{array}{l}\text { Total } \\
\text { Gas }\end{array}$ & $\begin{array}{c}\text { Total } \\
011\end{array}$ & $\begin{array}{c}\text { Total } \\
\text { Wood \& Coal }\end{array}$ & $\begin{array}{l}\text { Total Residential } \\
\text { Energy Consumption }\end{array}$ \\
\hline $\begin{array}{l}1981 \\
1982 \\
1983 \\
1984 \\
1985 \\
1986 \\
1987 \\
1988 \\
1989 \\
1990 \\
1991 \\
1992 \\
1993 \\
1994 \\
1995\end{array}$ & $\begin{array}{l}2.4644 \\
2.4898 \\
2.5955 \\
2.8050 \\
2.8935 \\
3.0282 \\
3.1357 \\
3.2422 \\
3.3714 \\
3.4987 \\
3.6154 \\
3.7303 \\
3.8458 \\
3.9552 \\
4.1989\end{array}$ & $\begin{array}{l}4.6647 \\
4.6746 \\
4.5586 \\
4.7091 \\
4.8478 \\
5.3069 \\
5.6121 \\
5.7208 \\
5.8018 \\
5.8708 \\
5.8677 \\
5.8525 \\
5.8412 \\
5.8102 \\
5.9081\end{array}$ & $\begin{array}{l}1.5434 \\
1.3176 \\
1.4125 \\
1.4104 \\
1.4377 \\
1.5311 \\
1.5558 \\
1.1577 \\
1.1296 \\
1.0981 \\
1.0618 \\
1.0328 \\
1.0082 \\
0.9737 \\
0.9439\end{array}$ & $\begin{array}{l}0.2739 \\
0.3956 \\
0.5127 \\
0.5185 \\
0.5057 \\
0.4933 \\
0.4812 \\
0.4693 \\
0.4578 \\
0.4465 \\
0.4355 \\
0.4248 \\
0.4143 \\
0.4041 \\
0.3942\end{array}$ & $\begin{array}{r}8.9464 \\
8.8776 \\
9.0793 \\
9.4431 \\
9.6848 \\
10.3595 \\
10.7848 \\
10.5900 \\
10.7606 \\
10.9141 \\
10.9805 \\
11.0404 \\
11.1096 \\
11.1432 \\
11.4451\end{array}$ \\
\hline & & & & & \\
\hline Year & $\begin{array}{c}\text { Total } \\
\text { Electricity }\end{array}$ & $\begin{array}{l}\text { Total } \\
\text { Gas }\end{array}$ & $\begin{array}{c}\text { Total } \\
011\end{array}$ & $\begin{array}{c}\text { Total } \\
\text { Wood \& Coal }\end{array}$ & $\begin{array}{l}\text { Total Residential } \\
\text { Energy Consumption }\end{array}$ \\
\hline $\begin{array}{l}1981 \\
1982 \\
1983 \\
1984 \\
1985 \\
1986 \\
1987 \\
1988 \\
1989 \\
1990 \\
1991 \\
1992 \\
1993 \\
1994 \\
1995\end{array}$ & $\begin{array}{l}27.5 \% \\
28.0 \% \\
28.6 \% \\
29.7 \% \\
29.9 \% \\
29.2 \% \\
29.1 \% \\
30.6 \% \\
31.3 \% \\
32.1 \% \\
32.9 \% \\
33.8 \% \\
34.6 \% \\
35.5 \% \\
36.7 \%\end{array}$ & $\begin{array}{l}52.1 \% \\
52.7 \% \\
50.2 \% \\
49.9 \% \\
50.1 \% \\
51.2 \% \\
52.0 \% \\
54.0 \% \\
53.9 \% \\
53.8 \% \\
53.4 \% \\
53.0 \% \\
52.6 \% \\
52.1 \% \\
51.6 \%\end{array}$ & $\begin{array}{l}17.3 \% \\
14.8 \% \\
15.6 \% \\
14.9 \% \\
14.8 \% \\
14.8 \% \\
14.4 \% \\
10.9 \% \\
10.5 \% \\
10.1 \% \\
9.7 \% \\
9.4 \% \\
9.1 \% \\
8.7 \% \\
8.2 \%\end{array}$ & $\begin{array}{l}3.1 \% \\
4.5 \% \\
5.6 \% \\
5.5 \% \\
5.2 \% \\
4.8 \% \\
4.5 \% \\
4.4 \% \\
4.3 \% \\
4.1 \% \\
4.0 \% \\
3.8 \% \\
3.7 \% \\
3.6 \% \\
3.4 \%\end{array}$ & $\begin{array}{l}100.0 \% \\
100.0 \% \\
100.0 \% \\
100.0 \% \\
100.0 \% \\
100.0 \% \\
100.0 \% \\
100.0 \% \\
100.0 \% \\
100.0 \% \\
100.0 \% \\
100.0 \% \\
100.0 \% \\
100.0 \% \\
100.0 \%\end{array}$ \\
\hline
\end{tabular}


IABLE 4.17. High Fuel Prices

(QUADS)

\begin{tabular}{|c|c|c|c|c|c|}
\hline Year & $\begin{array}{l}\text { Total } \\
\text { Electricity }\end{array}$ & $\begin{array}{l}\text { Total } \\
\text { Gas }\end{array}$ & $\begin{array}{c}\text { Total } \\
011\end{array}$ & $\begin{array}{c}\text { Total } \\
\text { Wood \& Coal }\end{array}$ & $\begin{array}{l}\text { Total Residential } \\
\text { Energy Consumption }\end{array}$ \\
\hline $\begin{array}{l}1981 \\
1982 \\
1983 \\
1984 \\
1985 \\
1986 \\
1987 \\
1988 \\
1989 \\
1990 \\
1991 \\
1992 \\
1993 \\
1994 \\
1995\end{array}$ & $\begin{array}{l}2.4644 \\
2.4898 \\
2.5955 \\
2.8050 \\
2.8935 \\
2.9953 \\
3.0697 \\
3.1422 \\
3.2379 \\
3.3325 \\
3.4158 \\
3.4964 \\
3.5768 \\
3.6486 \\
3.8386\end{array}$ & $\begin{array}{l}4.6647 \\
4.6746 \\
4.5586 \\
4.7091 \\
4.8478 \\
5.2500 \\
5.5072 \\
5.5589 \\
5.5780 \\
5.5832 \\
5.5047 \\
5.4069 \\
5.3080 \\
5.1794 \\
5.1409\end{array}$ & $\begin{array}{l}1.5434 \\
1.3176 \\
1.4125 \\
1.4104 \\
1.4377 \\
1.5208 \\
1.5375 \\
1.5056 \\
1.4764 \\
1.4440 \\
1.4081 \\
1.3763 \\
1.3472 \\
1.3118 \\
1.2932\end{array}$ & $\begin{array}{l}0.2739 \\
0.3956 \\
0.5127 \\
0.5185 \\
0.5057 \\
0.4933 \\
0.4812 \\
0.4693 \\
0.4578 \\
0.4465 \\
0.4355 \\
0.4248 \\
0.4143 \\
0.4041 \\
0.3942\end{array}$ & $\begin{array}{r}8.9464 \\
8.8776 \\
9.0793 \\
9.4431 \\
9.6848 \\
10.2594 \\
10.5955 \\
10.6760 \\
10.7501 \\
10.8062 \\
10.7641 \\
10.7044 \\
10.6463 \\
10.5439 \\
10.6669\end{array}$ \\
\hline Year & $\begin{array}{l}\text { Total } \\
\text { Electricity }\end{array}$ & $\begin{array}{l}\text { Total } \\
\text { Gas }\end{array}$ & $\begin{array}{c}\text { Total } \\
011\end{array}$ & $\begin{array}{l}\text { Total } \\
\text { Wood \& Coal }\end{array}$ & $\begin{array}{l}\text { Total Residential } \\
\text { Energy Consumption }\end{array}$ \\
\hline $\begin{array}{l}1981 \\
1982 \\
1983 \\
1984 \\
1985 \\
1986 \\
1987 \\
1988 \\
1989 \\
1990 \\
1991 \\
1992 \\
1993 \\
1994 \\
1995\end{array}$ & $\begin{array}{l}27.5 \% \\
28.0 \% \\
28.6 \% \\
29.7 \% \\
29.9 \% \\
29.2 \% \\
29.0 \% \\
29.4 \% \\
30.1 \% \\
30.8 \% \\
31.7 \% \\
32.7 \% \\
33.6 \% \\
34.6 \% \\
36.0 \%\end{array}$ & $\begin{array}{l}52.1 \% \\
52.7 \% \\
50.2 \% \\
49.9 \% \\
50.1 \% \\
51.2 \% \\
52.0 \% \\
52.1 \% \\
51.9 \% \\
51.7 \% \\
51.1 \% \\
50.5 \% \\
49.9 \% \\
49.1 \% \\
48.2 \%\end{array}$ & $\begin{array}{l}17.3 \% \\
14.8 \% \\
15.6 \% \\
14.9 \% \\
14.8 \% \\
14.8 \% \\
14.5 \% \\
14.1 \% \\
13.7 \% \\
13.4 \% \\
13.1 \% \\
12.9 \% \\
12.7 \% \\
12.4 \% \\
12.1 \%\end{array}$ & $\begin{array}{l}3.1 \% \\
4.5 \% \\
5.6 \% \\
5.5 \% \\
5.2 \% \\
4.8 \% \\
4.5 \% \\
4.4 \% \\
4.3 \% \\
4.1 \% \\
4.0 \% \\
4.0 \% \\
3.9 \% \\
3.8 \% \\
3.7 \%\end{array}$ & $\begin{array}{l}100.0 \% \\
100.0 \% \\
100.0 \% \\
100.0 \% \\
100.0 \% \\
100.0 \% \\
100.0 \% \\
100.0 \% \\
100.0 \% \\
100.0 \% \\
100.0 \% \\
100.0 \% \\
100.0 \% \\
100.0 \% \\
100.0 \%\end{array}$ \\
\hline
\end{tabular}


IABLE 4.18. Low Fuel Prices

(QUADS)

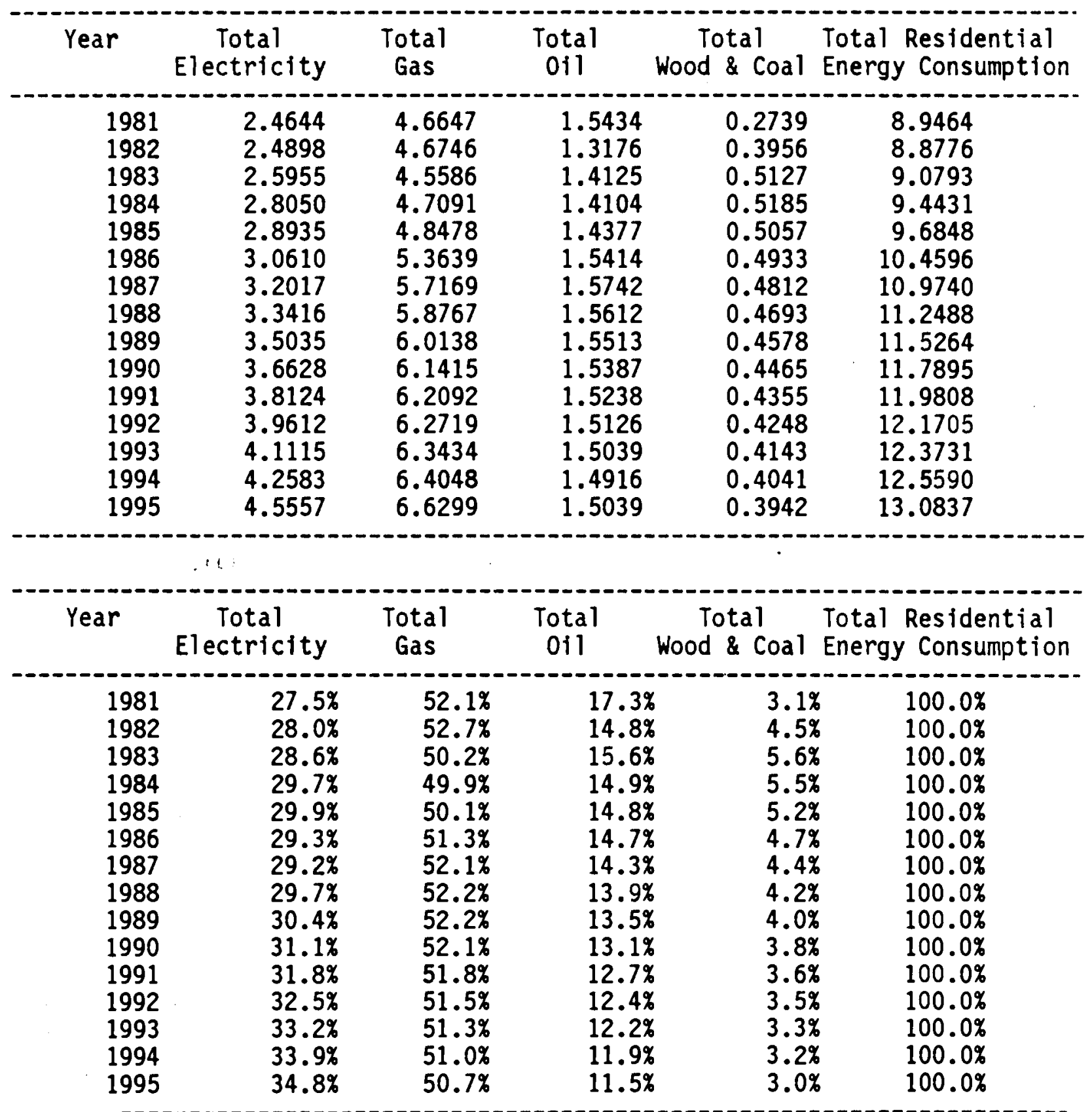


IABLE 4.19. High Electric Prices, Low Gas and $0 i 1$ Prices (QUADS)

\begin{tabular}{|c|c|c|c|c|c|}
\hline Year & $\begin{array}{c}\text { Total } \\
\text { Electricity }\end{array}$ & $\begin{array}{l}\text { Total } \\
\text { Gas }\end{array}$ & $\begin{array}{l}\text { Total } \\
\text { O11 }\end{array}$ & $\begin{array}{c}\text { Total } \\
\text { Wood \& Coal }\end{array}$ & $\begin{array}{l}\text { Total Residential } \\
\text { Energy Consumption }\end{array}$ \\
\hline $\begin{array}{l}1981 \\
1982 \\
1983 \\
1984 \\
1985 \\
1986 \\
1987 \\
1988 \\
1989 \\
1990 \\
1991 \\
1992 \\
1993 \\
1994 \\
1995\end{array}$ & $\begin{array}{l}2.4644 \\
2.4898 \\
2.5955 \\
2.8050 \\
2.8935 \\
2.9940 \\
3.0657 \\
3.1342 \\
3.2244 \\
3.3123 \\
3.3877 \\
3.4591 \\
3.5288 \\
3.5890 \\
3.7571\end{array}$ & $\begin{array}{l}4.6647 \\
4.6746 \\
4.5586 \\
4.7091 \\
4.8478 \\
5.3663 \\
5.7248 \\
5.8927 \\
6.0412 \\
6.1827 \\
6.2663 \\
6.3476 \\
6.4406 \\
6.5261 \\
6.7961\end{array}$ & $\begin{array}{l}1.5434 \\
1.3176 \\
1.4125 \\
1.4104 \\
1.4377 \\
1.5417 \\
1.5751 \\
1.5630 \\
1.5542 \\
1.5430 \\
1.5297 \\
1.5205 \\
1.5140 \\
1.5043 \\
1.5214\end{array}$ & $\begin{array}{l}0.2739 \\
0.3956 \\
0.5127 \\
0.5185 \\
0.5057 \\
0.4933 \\
0.4812 \\
0.4693 \\
0.4578 \\
0.4465 \\
0.4355 \\
0.4248 \\
0.4143 \\
0.4041 \\
0.3942\end{array}$ & $\begin{array}{r}8.9464 \\
8.8776 \\
9.0793 \\
9.4431 \\
9.6848 \\
10.3953 \\
10.8468 \\
11.0592 \\
11.2776 \\
11.4845 \\
11.6192 \\
11.7519 \\
11.8978 \\
12.0235 \\
12.4689\end{array}$ \\
\hline Year & $\begin{array}{c}\text { Total } \\
\text { Electricity }\end{array}$ & $\begin{array}{l}\text { Total } \\
\text { Gas }\end{array}$ & $\begin{array}{c}\text { Total } \\
011\end{array}$ & $\begin{array}{c}\text { Total } \\
\text { Wood \& Coal }\end{array}$ & $\begin{array}{l}\text { Total Residential } \\
\text { Energy Consumption }\end{array}$ \\
\hline $\begin{array}{l}1981 \\
1982 \\
1983 \\
1984 \\
1985 \\
1986 \\
1987 \\
1988 \\
1989 \\
1990 \\
1991 \\
1992 \\
1993 \\
1994 \\
1995\end{array}$ & $\begin{array}{l}27.5 \% \\
28.0 \% \\
28.6 \% \\
29.7 \% \\
29.9 \% \\
28.8 \% \\
28.3 \% \\
28.3 \% \\
28.6 \% \\
28.8 \% \\
29.2 \% \\
29.4 \% \\
29.7 \% \\
29.8 \% \\
30.1 \%\end{array}$ & $\begin{array}{l}52.1 \% \\
52.7 \% \\
50.2 \% \\
49.9 \% \\
50.1 \% \\
51.6 \% \\
52.8 \% \\
53.3 \% \\
53.6 \% \\
53.8 \% \\
53.9 \% \\
54.0 \% \\
54.1 \% \\
54.3 \% \\
54.5 \%\end{array}$ & $\begin{array}{l}17.3 \% \\
14.8 \% \\
15.6 \% \\
14.9 \% \\
14.8 \% \\
14.8 \% \\
14.5 \% \\
14.1 \% \\
13.8 \% \\
13.4 \% \\
13.2 \% \\
12.9 \% \\
12.7 \% \\
12.5 \% \\
12.2 \%\end{array}$ & $\begin{array}{l}3.19 \\
4.5 \\
5.69 \\
5.5 \\
5.2 \\
4.7 \\
4.4 \\
4.29 \\
4.19 \\
3.9 \\
3.79 \\
3.6 \% \\
3.5 \\
3.4 \\
3.29\end{array}$ & $\begin{array}{l}100.0 \% \\
100.0 \% \\
100.0 \% \\
100.0 \% \\
100.0 \% \\
100.0 \% \\
100.0 \% \\
100.0 \% \\
100.0 \% \\
100.0 \% \\
100.0 \% \\
100.0 \% \\
100.0 \% \\
100.0 \% \\
100.0 \%\end{array}$ \\
\hline
\end{tabular}




\subsection{SUMMARY}

Several significant conclusions emerge from this study regarding future fuel shares. The most likely scenario is for the electricity share to continue to increase over the next 10 years so that electricity accounts for 35 percent of residential fuel use in 1995. This growth is largely at the expense of oil use but the gas share and wood share fall gradually as well. 0il use is largely limited to space and, to a lesser extent, water heating in the North East. The ease of use and cleanliness of gas and electric heat in addition to the relative increase in the price of oil has resulted in significant substitution away from oil. This trend is predicted to continue even with falling relative oil prices between now and 1995 .

There are, however, a considerable number of factors that could significantly alter the picture from that described above. For example, rising electricity prices combined with falling gas and oil prices could lead to no further penetration of electricity. Rapid penetration of the electric heat pump could, on the other hand, lead to electricity penetration to 38.5 percent of fuel use in 1995, up from 29.9 percent in 1985. Such uncertainties could have significant impacts one way or the other on the likelihood of electricity supply shortfalls in the 1990's.

Overall, the forecasts of aggregate fuel use are higher than have been projected by such forecasters as the Energy Information Administration (EIA). The EIA base case forecasts 10.03 quads of energy use in 1995 compared to our 11.88 quads. This difference is largely due to energy prices; our all high price case is approximately the same as the EIA base case and total energy use in our all high price case is 10.66 quads.

Among the factors likely to have an impact on future fuel shares, gas prices are likely to be most important followed by electricity prices, trend penetration of heat pumps, oil prices, and population shift to the South and West. Income was found to have little effect on fuel shares.

A significant finding was the prevalence of auxiliary and multi-fuel heating capability in the residential sector; 20 to 35 percent, depending on primary heating fuel, of single family homes have dual-fuel capability. In particular, 35 percent of homes heated primarily with oil have multifuel capability and used this capability to provide a substantial proportion of

(a) See EIA, 1986, p.48. 
their heating requirements in 1981. The prevalence of dual-fuel heating capability is an apparent response to the volatility and uncertainty in oil prices. Because significant dual-fuel capability exists, many households are well situated to respond easily and quickly to oil price shocks and oil shortages. 


\section{REFERENCES}

Adams, R.C., D.B. Belzer, J.M. Fang, K.L. Imhoff, D.H. Lax, R.J. Moe, J.M. Roop, and A.R. Wusterbarth. 1985. A Retrospective Analysis of Energy Use and Conservation Trends: 1972-1982. PNL-5026, Pacific Northwest Laboratory, Richland, Washington.

Adams, R.C., and A.D. Rockwood. 1983. Impact of Improved Building Thermal Efficiency on Residential Energy Demand. Pacific Northwest Laboratory, Richland, Washington.

Amemiya, T. 1981. "Qualitative Response Models: A Survey." Journal of Economic Literature. XIX: 1483-1536.

Arthur D. Little, Inc. 1981. Estimation of Conservation Penetration for the Southern Cal i fornia Gas Company Service Area, 1981-1986. Report to the Southern California Gas Co. Los Angeles, California.

Bogue, Donald J. 1985. The Population of the United States: Historical Trends and Future Prospects. The Free Press, New York.

Bohi, D.R. 1981. Analyzing Demand Behavior: A Study of Energy Elasticities. Johns Hopkins Press for Resources for the Future, Baltimore.

Copper, G. and A. Scott, "The Economics of House Heating: Further Findings." Energy Economics. 4(2):134-138.

Cambridge Systematics, Inc. 1981. The Residential End-Use Energy Planning System. Final Report No. EPRI RP 1211-2 The Electric Power Research Institute, Palo Alto, California.

Charles River Associates, Inc. 1980. Consumer Choice and Market Penetration of New Technologies: Application of a Discrete Choice Model. Report No. CRA-423, Boston, Massachusetts.

Energy Information Administration (EIA). 1986. Annual Energy Outlook: 1985. Washington, D.C.

Edmonds, J.E. 1978. "A Guide to Price Elasticities of Demand for Energy: Studies and Methodologies." Institute for Energy Analysis, Oak Ridge, Tenn. (ORAU/IEA-78-15(R)).

Griliches, Z. 1957. "Hybrid Corn: An Exploration of the Economics of Technological Change." Econometrica, 25: 501-22.

Hartman, R. S. 1979. Discrete Consumer Choice Among Alternative Fuels and Technologies for Residential Energy-Using Appliances. Energy Laboratory Working Paper No. MIT-EL 79-049WP.

Hartman, R. S. 1982a. "A Note on the Use of Aggregate Data in Individual Choice Models: Discrete Consumer Choice Among Alternative Fuels for Residential Appliances." Journal of Econometrics 18. 
Hartman, R. S. 1982b. "Consumer Choice and Alternative Fuels and Appliance Technologies: An Analysis of the Effects of Alternative Conservation Strategies." MIT Energy Laboratory Working Paper No. MIT-EL 82-036WP. Cambridge, Massachusetts.

Hartman, R. S. 1982c. "The Appropriateness of Conditional Logit for the Modeling of Residential Fuel Choice." Land Economics. 58(4): 478-487.

Hartman, R. S. 1984. "The Importance of Technology and Fuel Choice in the Analysis of Utility-Sponsored Conservation Strategies for Residential Water Heating." The Energy Journal. 5(3): 99-118.

Hartman, R. S., and W. Wallace. 1982. "Assessment of the Appropriate Methods of Incorporating Appliance Engineering Analyses and Data Into Residential End-Use Demand Models." Report No. EPR EA 4146, the Electric Power Research Institute, Palo Alto, California.

Hausman, J. A. 1979. "Individual Discount Rates and the Purchase and Utilization of Energy-Using Durables." Bell Journal of Economics, 10 Spring: $33-54$.

Henson, S.E. 1984. "Electricity Demand Elasticities Under Increasing Block Rates." Southern Economic Journal. 51 (1): 147-156.

Hirst, E., and J. Carney. 1978. The ORNL Engineering-Economic Model of Residential Energy Use Oak Ridge National Laboratory Report No. ORNL/CON-24. Oak Ridge, Tennessee.

Johnson, R. C., and D. L. Kaserman. 1983. "Housing Market Capitalization of Energy Saving Durable Good Investments." Economic Inquiry. XXI July: 374-386.

Judge, G.G., W.E. Griffiths, R. Carter Hill, T-C Lee. The Theory and Practice of Econometrics. John Wiley and Sons, Inc., New York: 583-620.

Mansfield, E. 1961. "Technological Change and the Rate of Imitation." Econometrica 29: 741-66.

Marchetti, C. and N. Nakicenovic. 1979. "The Dynamics of Energy Systems and the Logistics Substitution Model." International Institute for Applied Systems Analysis, Laxenberg, Austria.

McDougal1, G. H.G., J. D. Claxton, J.R. Brent Ritchie, and C. D. Anderson. 1981. "Consumer Energy Research: A Review." Journal of Consumer Research 8 (3): 343-354.

Neels, K. 1982. "Reducing Energy Consumption in Housing: An Assessment of Alternatives." International Regional Science Review. 7 (1): 69-81.

Parti, M., and C. Parti. 1980. "The Total and Appliance-Specific Conditional Demand for Electricity in the Household Sector." Bell Journal of Economics. II (1): 309-321. 
Paterka, V. 1977. "Macrodynamics of Technological Change: Market Penetration by New Technologies." International Institute for Applied System Analysis, Laxenberg, Austria.

Reilly, J.M. 1986. "The PNL Residential Model: Methodology." Pacific Northwest Laboratory, Richland, Washington.

Scheer, R.M. 1985. "The Effects of 011 Price Shocks on the Energy Use Intensity of the U.S. Economy." Pacific Northwest Laboratory, Richland, Washington.

Shankle, S.A. and J.M. Reilly. 1986. "Auxiliary Heating in the Residential Sector." Pacific Northwest Laboratory, Richland, Washington.

Taylor, L.D. 1977. "The Commercial Demand for Energy: A Review of Existing Knowledge." Department of Economics, University of Arizona.

U.S. Bureau of the Census. 1984. Statistical Abstract of the United States: 1985. U.S. Government Printing Office, Washington, D.C.

U.S. Department of Energy. 1985. Increasing Competition in the Natural Gas Market. U.S. Government Printing Office, Washington D.C.

Energy Information Administration. 1984. Residential Energy Consumption and Expenditures by End Use for 1978, 1980, and 1981. U.S. Department of Energy, Washington D.C. 


\section{DISTRIBUTION}

No. of

Copies

OFFSITE

30

DOE Technical Information Center

10

Barry McNutt
DOE Office of Policy Integration 1000 Independence Ave., S.W.

Washington, D.C. 20585

Diane Pirkey

DOE Office of Policy Integration

1000 Independence Ave., S.W.

Washington, D.C. 20585

Dr. Fred Abel

DOE Office of Building and Community Systems

1000 Independence Ave., S.W.

Washington, D.C. 20585

David Meyer

DOE Office of Coal and Electricity Policy

1000 Independence Ave., S.W.

Washington, D.C. 20585

Dick Holt

DOE Office of Policy Integration

1000 Independence Ave., S.W.

Washington, D.C. 20585

Peggy Podolak

DOE Office of Policy Integration

1000 Independence Ave., S.W.

Washington, D.C. 20585

Carmen Difiglio

DOE Office of Policy Integration 1000 Independence Ave., S.W.

Washington, D.C. 20585
Dan Santini

Argonne National Lab 9700 South Cass Ave., Argonne, IL 60439

Charles Klotz

Argonne National Lab 9700 South Cass Ave., Argonne, IL 60439

Mark Levine

Lawrence Berkeley National Laboratory

Berkeley, CA 94720

Jim McMahon

Lawrence Berkely National Laboratory

Berkeley, CA 94720

Jayant Sathaye

Lawrence Berkeley National Laboratory

Berkeley, CA 94720

Roger Naill

Applied Energy Services

1925 N Lynn

Arlington, VA

Jerome LaMontagne

Brookhaven National Lab

Upton, NY 11973

Alex Haynes

DOE Office of Policy

Planning and Analysis 1000 Independence Ave. SW Washington, D.C. 20585 
No. of

Copies

Vito Stagliano

DOE Office of Policy Integration

1000 Independence Ave., SW Washington, DC 20585

Kenneth Friedman

DOE Office of Conversation and Renewable Energy 1000 Independence Ave., SW Washington, DC 20585

Harvey Major

DOE Office of Conservation and Renewable Energy

1000 Independence Ave., SW

Washington, DC 20585

Mike King

Synergic Resource Corporation

1424 4th Avenue., Suite 820

Seattle, WA 98101-2208
No. of

Copies

ON-SITE

DOE Richland Operations Office

J. J. Sutey

30 Pacific Northwest Laboratory

J. M. Reilly (10)

R. M. Scheer (5)

D. B. Belzer

R. J. Moe

J. M. Roop

J. S. Pomykala (4)

S. A. Shankle (4)

J. A. Edmonds

M. S. Klan

R. C. Adams

Publishing Coordination (2)

Technical Information (5) 